\title{
A PALAVRA E 0 IMPÉRIO: \\ A ARTE DA LINGUA BRASILICA \\ E A CONQUISTA DO MARANHÃO
}

\author{
Pablo Antonio Iglesias Magalhães \\ Deptartamento de História da Universidade Federal \\ da Bahia e Centro Universitário Jorge Amado
}

\section{Resumo}

O presente artigo faz uma análise da primeira edição da Arte da lingua brasilica, do jesuíta Luís Figueira. São investigados os aspectos históricos que levaram à publicação dessa gramática, assim como seu uso pelos jesuítas com o objetivo de estabelecer alianças com os povos indígenas na conquista do Maranhão e nas guerras contra a Companhia das Índias Ocidentais.

\section{Pallavras-chave}

Arte da lingua brasilica $\bullet$ Luís Figueira $•$ Maranhão $•$ Brasil holandês.

\section{Contato:}

Rua Carinhanha, 49 - Torre Sul, Apt. 205.

Condomínio Vila Jardim - Jardim Brasília

41.1301-35 - Salvador - Bahia

E-mail:pimagalhaes@yahoo.com.br 


\title{
THE WORD AND THE EMPIRE: THE ARTE DA LINGUA BRASILICA AND THE CONQUEST OF MARANHÃO
}

\author{
Pablo Antonio Iglesias Magalhães \\ Departamento de História da Universidade Federal \\ da Bahia and Centro Universitário Jorge Amado
}

\begin{abstract}
The present article makes an analysis of the first edition of the Arte da lingua brasilica, of the jesuit Luís Figueira. The historical aspects that had taken the publication of this grammar are investigated, as well as its use for the jesuits with the objective to establish alliances with the aboriginal peoples in the conquest of the Maranhão and the wars against the West-Indische Compagnie.
\end{abstract}

\section{Keywords}

Arte da lingua brasilica • Luís Figueira • Maranhão • Dutch Brazil.

\section{Contact:}

Rua Carinhanha, 49 - Torre Sul, Apt. 205.

Condomínio Vila Jardim - Jardim Brasília

41.1301-35 - Salvador - Bahia

E-mail: pimagalhaes@yahoo.com.br 


\section{As missões no Maranhão e Luís Figueira}

Os povos indígenas foram agentes de primeira ordem nas guerras travadas entre as nações europeias para conquistar o norte da América portuguesa na primeira metade do século XVII. A ocupação do Maranhão pelos europeus teve início com a chegada dos franceses à ilha de Upaon-Açu (ilha de São Luís) em 1612, numa expedição liderada por Daniel de La Touche, senhor de La Ravardière, que tentou fundar colônias no Brasil. Os franceses estabeleceram um núcleo de povoamento chamado França Equinocial e o fort Saint Louis, que deu início à cidade de São Luís.

Entretanto, portugueses e indígenas, sob o comando de Jerônimo de Albuquerque, expulsaram os franceses em 1615 na batalha de Guaxenduba e passaram a ter controle das terras maranhenses. Em seguida, foi estabelecido o Estado do Maranhão, unidade administrativa criada em 13 de junho de 1621 por Filipe III, rei da Espanha, no norte da América portuguesa, que compreendia ainda as capitanias do Pará, Piauí e do Ceará.

A mudança do status administrativo do Maranhão não foi acompanhada de uma modificação no seu sistema defensivo. Com menos de 400 habitantes europeus, a defesa do Maranhão passava pela aliança com os indígenas. $\mathrm{O}$ governador-geral Gaspar de Sousa observou "que sem jndios não se pode faser

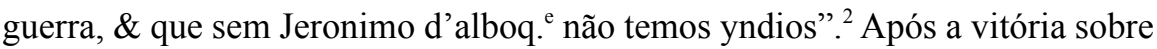
os franceses no Maranhão e na iminência do término da Pax Hispanica (16091618) com as Províncias Unidas, a coroa ibérica já estava consciente de que precisava dos povos indígenas, particularmente dos tupinambás, para efetivar a defesa do litoral do Brasil. Os representantes do governo em Castela, Portugal e no Brasil também reconheciam que não poderiam ficar dependendo dos humores de particulares na organização e comando das tropas indígenas.

As tentativas de utilizar oficiais militares na administração das aldeias fracassou no Brasil, por volta de 1620, em decorrência da postura dos militares junto aos tupinambás. Os missionários jesuítas foram reconhecidos, então, como os mais capazes mediadores culturais entre os interesses ibéricos e povos indígenas, sendo que já possuíam mais de sete décadas de experiência na conversão, catequese e administração de aldeias tupinambás, iniciada no Recôncavo baiano

\footnotetext{
1 VARNHAGEN, Francisco Adolfo de. Historia geral do Brazil, por um socio do Instituto historico do Brazil. Madri, 1854, vol. 1, p. 333.

2 Cartas de instruções secretas do governador Gaspar de Sousa ao capitão-mor Alexandre de Moura, para a definitiva conquista do Maranhão. In: Livro Primeiro do Governo do Brasil 1607-1633. Rio de Janeiro: Imprensa Nacional, 1958, p. 117.
} 
em 1549. ${ }^{3}$ Além disso, os jesuítas eram as maiores autoridades na língua falada pelos povos indígenas que habitavam o litoral da América portuguesa. Segundo Pero de Magalhães Gândavo,

a língua de que usam, toda pela costa é uma, ainda que em certos vocábulos difere n'algumas partes, mas não de maneira que deixem uns aos outros de entender, e isto até altura de vinte e sete graus, que daí por diante há outra gentilidade, de que nós não temos tanta notícia, que falam já outra língua. Esta de que trato, que é geral pela costa, é muito branda, e a qualquer nação fácil de tomar. ${ }^{4}$

Fernão Cardim, em fins do século XVI, observa o alcance da língua tupi nas regiões litorâneas em direção ao interior do Brasil, incluída a migração de povos costeiros para a região do Ceará e Maranhão, como os caetés, que seguiram em direção ao norte para evitar ataques dos portugueses. Segundo Cardim, na América portuguesa,

há muitas e várias nações de diferentes línguas, porém uma é a principal que compreende algumas dez nações de índios; estes vivem na costa do mar, e em uma grande corda do sertão, porém são todos estes de uma só língua, ainda que em algumas palavras discrepam e esta é a que entendem os portugueses; é fácil, e elegante, e suave, e copiosa, a dificuldade está em ter muitas composições. (...) Eram tantos os desta casta que parecia impossível poderem-se extinguir, mas os portugueses tanto os têm combatido que quase todos são mortos, e lhes têm tal medo que despovoam a costa e fogem pelo sertão adentro até trezentas ou quatrocentas léguas. ${ }^{5}$

Dominar esse conjunto linguístico era fundamental para doutrinar os povos que as falavam. Ao longo do século XVI, segundo John Monteiro, "a primeira língua geral foi perdendo suas inflexões locais e regionais em função da sua adoção, sistematização e expansão enquanto idioma colonial". ${ }^{6}$ Sob a influência da obra de Elio Antonio de Nebrija, os governos ibéricos perceberam a importância do uso de sistemas gramaticais como instrumento para consolidar seus objetivos políticos de conquista e de manutenção dos impérios ultramarinos, particularmente no continente americano.

3 AGNOLIN, Adone. Jesuitas e selvagens: a negociação da fé no encontro catequético-ritual americano-tupi (séc. XVI-XVII). São Paulo: Humanitas / Fapesp, 2007, p. 431-435.

4 GÂNDAVO, Pero de Magalhães. Historia da prouincia sa[n]cta Cruz a que vulgarme[n]te chamam Brasil. Lisboa: na officina de Antonio Gonsaluez, 1576, fl. 33v.

5 CARDIM, Fernão. Tratados da terra e gente do Brasil. Rio de Janeiro: J. Leite, 1925, p. 95.

6 MONTEIRO, John Manuel. Traduzindo tradições: Gramáticas, vocabulários e catecismos em línguas nativas na América portuguesa. In: Os índios, nós. Lisboa: Museu nacional de Etnologia, 2000, p. 36-43. 
Os projetos coloniais ibéricos somados à catequização dos povos americanos pelos missionários católicos convergiram para a publicação de decodificadores de línguas desconhecidas aos europeus até o século XVI; em sua maioria línguas ágrafas, sendo que os portugueses, entre 1549 e 1697, publicaram 45 obras que contêm informação sobre línguas da África, Ásia e América, pertencentes a vários gêneros como tratados, cartilhas, catecismos e gramáticas. ${ }^{7} \mathrm{O}$ domínio da língua era o meio mais direto para a catequese. É precisamente este aspecto que transparece em muitos dos prefácios e prólogos das gramáticas de línguas indígenas, como é o caso do prólogo da Arte de la lengua quichua, do jesuíta Diego de Torres Rubio, publicada no Peru, em 1619: "Con los preceptos y reglas generales que van en este Arte de la lengua quichua, puede uno aprender a hablar congruamente lo suficiente y necesario que es menester para catequizar, confesar e predicar". ${ }^{8}$

A imposição de uma língua geral aos índios no Maranhão, falantes ou não do tupi, além de uma via para a conversão daqueles povos, era uma necessidade para a continuidade dos projetos coloniais ibéricos naquela região. O reduzido número de moradores e a falta de soldados confirmavam a urgência das autoridades em estabelecer o diálogo com os índios. Assim, a conquista e manutenção do Maranhão passariam, então, pela capacidade de comunicação com os povos indígenas da região. Isso foi ratificado após a derrota dos franceses no Maranhão, quando Alexandre de Moura e o governador do Brasil, d. Luís de Sousa, perceberam a necessidade de enviar para aquela região os religiosos que conhecessem a língua tupi.

Por essa razão, os primeiros religiosos do Brasil foram enviados para o Maranhão. Durante as lutas contra os franceses, frades carmelitas, os franciscanos frei Cosme de São Damião e frei Manoel Batista, além dos padres jesuítas Manuel Gomes e Diogo Nunes, acompanhando os soldados, demonstraram o quanto o domínio da língua geral foi determinante nos rumos da guerra. Em 1618, o Conselho da Fazenda enviou uma petição na qual pedia ao provincial de Nossa Senhora do Carmo no Brasil que enviasse religiosos para o Maranhão, argumentando que

na noua Conquista do Maranhão E Grão Para é neces. ${ }^{\text {ro }}$ hauer ministros q tratem da conuersão dos Infieis daquelas partes [e] para q nos ditos mostr. ${ }^{\circ \mathrm{E}} \mathrm{E}$ em seminários aprendão a lingua e possão doctrinar E ensinar a dita gente E nas residências se ponhão Releg. ${ }^{\circ \text { s }}(\ldots)$

7 BUESCU, Maria Leonor Carvalhao. A galáxia das línguas na época da expansão. Lisboa: Comissão Nacional para as Comemorações dos Descobrimentos Portugueses, 1992, p.70-191.

8 RUBIO, Diego Torres. Arte de la lengua quíchua. Peru, 1619, p. 2. 
que saibão bem a lingoa. E que do Brasil mande o prouincial Releg. ${ }^{.5}$ a dita Conq. ${ }^{\text {ta }}$ que saibão bem a lingoa para logo poder assistir nas Residências. ${ }^{9}$

Ainda em 1618, foram enviados para o Maranhão os franciscanos frei Felipe de São Boaventura, frei Sebastião do Rosário, frei Antonio da Marciana e frei Cristóvão de São José que subiu o rio Tocantins. Na margem esquerda estabeleceu um núcleo populacional, que recebeu o nome dos nativos do lugar, os índios camutás, estabelecendo a Vila Viçosa de Santa Cruz, onde havia de ser erigida a Capitania de Camutá, de Feliciano Coelho de Carvalho, em 1635.

O Maranhão foi elevado à custódia da Província de São Francisco em 1624, quando frei Cristovão de Lisboa chegou a Pernambuco, seguindo, depois, para São Luís. Os dez franciscanos que vieram de Portugal acompanhando o custódio, além do próprio, desconheciam a língua geral. Para prestar assistência a esse grupo, o Convento de Olinda determinou que cinco dos seus religiosos acompanhassem frei Cristovão ao Maranhão, incluindo frei Álvaro do Calvário e frei Francisco do Rosário, "línguas" experientes. O portuense frei Rosário recebeu o hábito dos menores no Convento de Nossa Senhora das Neves de Pernambuco a 24 de abril de 1591 e escreveu um Tratado dos ritos, costumes e linguas dos brasis e o Cathecismo da lingua brasilica, que Jaboatão afirma "ter a mão dos Olandezes na perda de Pernambuco". ${ }^{10}$ Afirmou Maria Adelina Amorim que "uma das acusações que se fazia aos capuchos era o desconhecimento das línguas nativas" e, com a execessão de frei Rosário, essa afirmação se justifica, visto que, dois anos após chegar ao Maranhão, frei Cristóvão de Lisboa ainda não dominava a língua geral. ${ }^{11}$

Alexandre de Moura e d. Luís de Sousa recorreram, também, ao provincial da Companhia de Jesus, Pedro de Toledo, em 1618. Segundo uma carta manuscrita do padre Manuel Gomes, Alexandre de Moura justificou sua petição ao provincial alegando "serem mais poderosas quatros palauras, dos Padres da Compa, $\mathrm{p}^{\mathrm{a}}$ com o gentio, que estaua pella parte dos franceses, que todas suas armas". ${ }^{12}$

9 Arquivo Histórico Ultramarino (AHU), Maranhão, caixa 1, documento 19. Consulta do Conselho da Fazenda ao rei Filipe II, sobre a petição do provincial da Ordem de Nossa Senhora do Carmo. 21 de março de 1618.

${ }^{10}$ CARDOSO, Jorge. Agiologio lusitano dos sanctos, e varoens illustres em virtude do Reino de Portugal, e suas conquistas. Lisboa: na Officina de Antonio Craesbeeck de Mello, 1666, t. III, p. 850. JABOATAM, Antonio de Santa Maria. Novo Orbe serafico brazilico, ou Chronica dos frades menores da provincia do Brazil. Rio de Janeiro: Tip. Maximiliano Gomes, 1858, t. I, liv. 1, p. 356.

${ }^{11}$ AMORIM, Maria Adelina. Os franciscanos no Maranhão e Grão-Pará: missão e cultura na primeira metade de seiscentos. Lisboa: Clepul, 2005, p. 125.

${ }^{12}$ Biblioteca Nacional de Portugal. MSS. 29, n. 31. GOMES, Manuel. Relação de uma expedição 
O provincial enviou o padre Diogo Nunes "insigne lingoa do Brasil", e o padre Manuel Gomes "p pregar e acodir, ao qe fose ncessario, por auer la hereges e saber tambem a lingoa". ${ }^{13}$

O padre Diogo Nunes morreu no Maranhão e o padre Manuel Gomes embarcou para a Espanha no dia 10 de março de 1620. No seu relatório da missão, esse jesuíta expressou a preocupação de que “(na) Europa não há um so pregador, que saiba a lingoa da gentilidade e lhe declarem a nossa Sancta fe". ${ }^{14}$ Para resolver esse problema e atender ao pedido do governo, a Companhia de Jesus enviou para o Maranhão a maior autoridade da sua época nos estudos da língua geral: o padre Luís Figueira.

A vida e as ações do padre Figueira ficaram conhecidas por conta da biografia publicada pelo historiador Serafim Leite em 1940, que editou, em anexo à obra, todos os seus escritos conhecidos ou a ele atribuídos. Luís Figueira nasceu em Almodóvar, entre 1574 e 1576, entrou para a Companhia de Jesus a 22 de janeiro de 1592, como noviço, no Colégio do Espírito Santo em Évora. Embarcou em 1602 para Salvador, residindo no Colégio da Bahia, centro intelectual da colônia, onde teve seu primeiro contato com as aldeias e a língua tupinambá. Conheceu, em seguida, o padre Francisco Pinto, "muito perito na língua brasílica e muito eloquente nela". Afirma o padre Jacinto de Carvalho que foi Francisco Pinto o mestre de Figueira na língua dos povos indígenas:

Havia pouco que [Figueira] tinha chegado ao Brasil, e principiava aprender a língua dos índios, em que depois, com as lições do padre Francisco, saiu tão consumado mestre, que compôs a Arte da lingua brasilica, obra que assim na disposição como na clareza das regras e preceitos, de todos os que sabem esta língua é julgada por perfeita, e os que a não sabem, por ela a aprendem com muita facilidade e perfeição. ${ }^{15}$

no norte do Brasil, pelo Ceará e Amazonas, acompanham Alexandre de Moura em 1618 em missão, 1621, jul. 2. fls., 1 v.

${ }^{13}$ Ibidem, fls. 2.

${ }^{14}$ Ibidem, fls. 8v.

${ }^{15}$ CARVALHO, Jacinto de. Crônica da Companhia de Jesus no Maranhão. São Luís: Alumar, 1995, p. 51 e 52. Um apógrafo manuscrito da Crônica de Jacinto de Carvalho está conservado na Biblioteca Pública de Évora. CXV/2-11, f. 346-63. O texto, de data incerta, foi escrito na primeira metade do século XVIII. Aliás, o fato de citar a Arte da língua brasilica com o nome primitivo indica que o padre Carvalho ainda conheceu a primeira edição do livro. 
Em 1607-1608, partindo de Pernambuco com 60 índios, empreende a expedição ao Maranhão, acompanhando o padre Francisco Pinto. ${ }^{16}$ No relato que deixou - a Relação da missão do Maranhão, datada de 26 de março de 1609 - descreveu Luís Figueira, em pormenor, todos os passos desta experiência e as dificuldades que levaram ao fracasso daquela empresa. O percurso, longo e penoso, por caminhos alagados, levou-os ao fim de dois meses à aldeia de Ibiapaba, no atual Ceará. Passaram depois à aldeia de Jurupariaçu, ou do principal Diabo Grande, onde foram informados da existência de franceses, assim como da hostilidade de outros povos indígenas. Ao fim de quatro meses na aldeia, decidiram-se a prosseguir para o Maranhão, quando se desencadearam os ataques contra a expedição. A 10 de janeiro de 1608, os índios, instigados pelos franceses, mataram Francisco Pinto, conseguindo Luís Figueira refugiar-se no mato, sendo resgatado pelo jesuíta Gaspar de Samperes que, de barco, o levou em segurança para o Rio Grande, de onde retornou para Pernambuco. ${ }^{17}$

Figueira assumiu, no Colégio de Olinda, o cargo de prefeito de estudos em 1610, fazendo, no ano seguinte, a 21 de setembro, a sua profissão solene e sendo nomeado reitor em 1612. Consultado pelas autoridades do Brasil quanto à forma de assegurar a conquista do norte, aconselhou o estabelecimento das missões entre os índios.

Na informação que escreve na Bahia em 26 de agosto de 1609, Dificuldades da missão do Maranhão, fornece relevantes dados sobre a extensão do território, os índios que o habitam e a ameaça de invasão pelos franceses. Em 1614, a conquista do Maranhão torna-se premente pela notícia da fundação da colônia francesa de São Luís que, em fins daquele ano, foi tomada pelos contingentes sob o comando de Alexandre de Moura, Jerônimo de Albuquerque e Diogo de Campos. Em seguida, prosseguiram as tropas para o Pará, fundando-se, em inícios de 1616, a cidade de Belém. Nos anos seguintes, a ameaça de invasão francesa cederia lugar ao temor de invasões neerlandesas.

Com o fim da Pax Hispanica em 1618, teve reinício a guerra entre a Espanha dos Habsburgo e as Províncias Unidas, com a subsequente organização de expedições militares neerlandesas em direção à América portuguesa. Se a própria capital do Brasil, Salvador, estava exposta a incursões militares do norte da

${ }^{16}$ CASTELNAU-L'ESTOILE, Charlotte de. Les ouvriers d'une vigne stérile: les jésuites et la conversion des indiens au Brésil, 1580-1620. Centre culturel Calouste Gulbenkian, 2000 , p. 435-437.

${ }^{17}$ MAGALHÃES, Pablo Antonio Iglesias; PARAÍSO, Maria Hilda Baqueiro (eds.). Cartas do padre Fernão Cardim (1608 - 1618). In: Clio, Dôssie Estudos Jesuíticos. UFPE, v. 27.2-2, 2009, p. $240-242$. 
Europa, a situação defensiva do Maranhão estava muito mais crítica: não havia efetivo militar e nem mesmo população capaz de defender o território. A afirmação do governador Gaspar de Sousa de que "sem índios não se pode fazer guerra" transformou-se no único modo de estabelecer um sistema defensivo viável para São Luís, fazendo com que, em 1621, o governador Diogo de Mendonça Furtado solicitasse ao provincial dos jesuítas a criação de uma missão no Maranhão, oferecendo para isso " 250 escudos de ouro". Furtado indicou, ainda, o "famoso pregador" Luís Figueira e o siciliano Benedito Amodei, "dois religiosos fortes e amantes da mortificação". ${ }^{18}$

Assim, em março de 1622, Figueira e Amodei chegam a São Luís. Isso desencadeou as primeiras manifestações contrárias dos moradores que queriam os jesuítas afastados dos índios, fato que terá pesado na entrega de vastos poderes aos franciscanos chefiados por frei Cristovão de Lisboa que, em 1625, chegou como superior da custódia, com todos os poderes eclesiásticos sobre indígenas e colonos, vindo como visitador eclesiástico com comissão do Santo Ofício.

Naqueles primeiros anos, iniciam os jesuítas os seus ministérios, lançando as bases de uma presença que se fez sentir, no Maranhão, a partir do Colégio de Nossa Senhora da Luz, em São Luís, e, no Pará, a partir do de Santo Alexandre, em Belém. Em breve se voltam os ânimos dos colonos contra os franciscanos em razão da alçada que detêm sobre os índios e da corajosa defesa da sua liberdade pelo custódio que acaba, porém, por largar essa jurisdição e, pouco depois, todas as demais, regressando os frades ao reino em 1636. Por essa época, restaram, no Maranhão, apenas vinte missionários, sendo dezenove portugueses e um siciliano, o jesuíta Benedito Amodei.

\section{Tabela 1}

\section{Número de missionários no Estado do Maranhão em 1639}

\begin{tabular}{|c|c|c|c|c|}
\hline $\begin{array}{c}\text { Companhia de } \\
\text { Jesus }\end{array}$ & $\begin{array}{c}\text { Ordem de Nossa } \\
\text { Senhora do Carmo } \\
\text { (São Luís) }\end{array}$ & $\begin{array}{c}\text { Ordem de Nossa } \\
\text { Senhora do Carmo } \\
\text { (Belém) }\end{array}$ & $\begin{array}{c}\text { Ordem de São } \\
\text { Francisco }\end{array}$ & Total \\
\hline 3 & 12 & 7 & 5 & 27 \\
\hline
\end{tabular}

Fonte: AHU, Maranhão. Caixa 1, documento 125. Anexo 2. Manuscrito autógrafo de Luiz Figueira, de 4 de setembro de 1639 .

18 Histoire de ce qui s'est passé en Ethiopie, Malabar, Brasil et en Indes orientales, tirée de lettres escrites és années 1620 iusques à 1624. Paris: Chez Sebastien Cramoisy, 1628, p. 158. 
Luís Figueira aproveita habilmente a oportunidade, preparando a transferência dos poderes para si e o seu instituto. Apresenta, em 1637, um Memorial sobre as terras e gente do Maranhao \& Grao-Para \& Rio das Amazonas, com base no qual vem o rei a conceder aos jesuítas, por alvará de 25 de julho de 1638, o governo temporal e espiritual sobre os índios e os poderes sobre o ordinário, criando-se uma prelazia a cargo do superior da Companhia. Se a medida não chegou a concretizar-se quanto à alçada diocesana, por embargos do bispo do Brasil, d. Pedro da Silva de Sampaio, e da Mesa da Consciência e Ordens, motivou uma série de consultas nos tribunais do reino e em Madri, que se viram interrompidas e alteradas no contexto da Restauração de 1640. No campo missionário, contudo, representou a entrega da alçada aos jesuítas. ${ }^{19}$ Figueira tentou separar os jesuítas do Maranhão da Província do Brasil "pelos impedimentos da Guerra de Pernambuco" que colocava o território do Brasil holandês entre São Luís e a Bahia, sede da Província. Sua petição foi negada pela Congregação em Roma. ${ }^{20}$

Achando-se no reino a negociar estas matérias e a recrutar missionários, partiu Luís Figueira para o Maranhão com amplos poderes e 16 religiosos em 1643. A ocasião era promissora em meios e em ânimos, apesar daquele território estar dominado pelos neerlandeses. O navio que os transportava afundou, de 29 para 30 de junho, salvando-se apenas 42 das 173 pessoas a bordo. Recusou Luís Figueira, com mais nove jesuítas, o convite do governador para entrar no barco em que se recolheram alguns náufragos, preferindo assistir espiritualmente aos que ficavam. Conforme o relato de um sobrevivente, Nicolau Teixeira, morreram uns no mar, outros às mãos dos índios; os dez jesuítas, chegando numa jangada à ilha do Marajó, foram mortos pelos aruáks.

Luís Figueira representava, para o Maranhão, o projeto cosmopolita da Companhia de Jesus, alicerçado intelectualmente nas heranças da escola de Salamanca e colocado ao serviço do padroado. Figueira legou, não obstante, o instrumento que permitiu abrir as vias de comunicação entre os missionários e os índios do Maranhão: a Arte da lingua brasilica. A importância de conhecer a editio princeps desse livro foi ressaltada por João Capistrano de Abreu numa carta a Guilherme Studart em 1893: "Da obra de Figueira publicaram-se diversas edições. Que fim, porém, levou a primeira edição? Ora, é esse documento capital para a gramática histórica da língua tupi". ${ }^{21}$

\footnotetext{
${ }^{19}$ AHU, Maranhão. Caixa 1, documento 125, 30 de maio de 1639.

${ }^{20}$ LEITE, Serafim (ed.). Novas cartas jesuiticas: de Nóbrega a Vieira. São Paulo: Companhia Editora Nacional, 1940, p. 254.

${ }^{21}$ ABREU João Capistrano de. Correspondência de Capistrano de Abreu. Rio de Janeiro: Ministério
} 


\section{A origem e o desaparecimento da Arte da lingua brasilica}

A publicação das gramáticas atendeu às demandas políticas de cada época e sociedade que as produziram. Essa afirmação torna-se um fato na medida em que examinamos os interesses que motivaram a publicação da Arte da lingua brasilica. Escrita por Luiz Figueira, essa gramática estava pronta em 1620, visto que a aprovação impressa na primeira edição data de Olinda, a 8 de dezembro de 1620, feita pelo jesuíta Manoel Cardoso.

A publicação de compêndios gramaticais que ensinavam as línguas dos povos ultramarinos onde foram instalados colégios jesuíticos era uma prática comum à Província portuguesa e estava integrado ao projeto de catequização empreendido por aquela Congregação religiosa. As constituições da Companhia de Jesus, escritas por Inácio de Loyola e adotadas em 1554, já observavam que

Exercitar-se-ão em pregações e lições sacras de tal forma que o povo fique edificado (...). Procurarão dominar bem a língua vernácula, ter previstas e à mão as coisas mais úteis para tal ministério e servir-se de todos os meios próprios. Desta sorte melhor se desempenharão do ofício e com mais fruto para as almas; Quando num colégio ou universidade se projectasse formar pessoas para serem enviadas aos Mouros, ou aos Turcos, estariam indicados o árabe ou o caldeu; como para ir aos Índios, o indiano, o mesmo se diga de outras línguas que, por motivos análogos, poderão ser mais úteis noutras regiões. ${ }^{22}$

Referentes ao Brasil, três gramáticas de línguas indígenas foram publicadas pelos jesuítas nos séculos XVI e XVII, sendo que houve mais uma que correu manuscrita e da qual não há notícias no presente. A obra fundadora da linguística brasílica foi a Arte da lingoa mais falada na costa do Brasil, publicada por José de Anchieta na Universidade de Coimbra em 1595, mas que já circulava manuscrita desde 1556. A segunda foi a de Luís Figueira, que na Aprovaçam de Manuel Cardoso, que examinara a obra por ordem do reitor do Colégio de Pernambuco, em 1620, declara que ao autor se devia "muito agradecimento, por facilitar com seu trabalho, o muito, que os que aprendem esta lingua Brasilica costumam ter não obstante a arte do P. Ioseph Anchieta, que por ser o primeiro parto ficou muy diminuta, \& confusa, como todos experimentamos". ${ }^{23}$

da Educação e Cultura, Instituto Nacional do Livro, 1954, vol. 1, p. 141.

${ }^{22}$ Cúria Provincial da Companhia de Jesus. Constituições da Companhia de Jesus e normas complementares. Lisboa: Livraria A. I., Braga, 1977, normas n. 402 e 447.

${ }^{23}$ FIGUEIRA, Luis. Arte da lingua brasilica. Lisboa: Manuel da Silva, s.d, fls. A2 r-v. 
Os aspectos etnolinguísticos das duas primeiras gramáticas jesuíticas, a de Anchieta e de Luiz Figueira, são conhecidos pelos linguistas. ${ }^{24}$ Os aspectos históricos da segunda, no entanto, foram ignorados pela historiografia. Serafim Leite concentrou seus estudos na Arte de Anchieta e relegou ao segundo plano a Arte de Figueira na História da Companhia de Jesus no Brasil (HCJB) e pouco avançou na biografia que escreveu daquele missionário no que toca à publicação da sua gramática. ${ }^{25}$ A existência de uma suposta primeira edição da Arte despertava o interesse dos principais historiadores brasileiros do século XIX. Alfredo do Vale Cabral tivera notícia de que Varnhagen encontrara um exemplar em Lisboa, mas ele próprio nunca o conheceu. ${ }^{26}$ João Capistrano de Abreu se intrigara com a primeira edição da gramática de Figueira e exprimiu a um amigo o seu "Desejo também (de) saber alguma cousa sobre a $1^{\mathrm{a}}$ edição da Gramática de Luís Figueira. No tempo de Inocêncio havia um exemplar". ${ }^{27}$

Sabe-se que a primeira edição da Arte é um livro raríssimo. Já era rara em meados do século XVII. Francisco de Brito Freyre, autor da História da guerra brasilica e governador de Pernambuco, cita a Arte da lingua brasilica, mas a atribui a José de Anchieta, indicando que nunca viu a de Figueira. ${ }^{28}$ Barbosa Machado, o autor da Biblioteca lusitana, sequer a menciona e Innocencio Francisco da Silva diz que nunca viu um exemplar da edição princeps da Arte de Figueira. Serafim Leite conheceu apenas o exemplar conservado na Biblioteca Nacional de Portugal que, aliás, é um documento histórico por trazer manuscrito seu primitivo local de conservação: "Col. ${ }^{\circ}$ do Parâ, 1682". ${ }^{29}$ Pertenceu originalmente ao Colégio de Santo Alexandre de Belém do Pará, tendo sido enviada para Lisboa, em meio a dez caixões com livros, por d. João de São José Queirós, no processo do confisco das bibliotecas jesuíticas no Maranhão e Grão-Pará em 1760. ${ }^{30}$

${ }^{24}$ BATISTA, Ronaldo de Oliveira. As linguas difficultosas e os linguas peritos. Artes de gramática jesuiticas no Brasil colonial dos séculos XVI e XVII. Dissertação de mestrado, Departamento de Linguística, FFLCH-USP, 2002.

${ }^{25}$ LEITE, Serafim. Luiz Figueira: A sua vida heróica e a sua obra literária. Lisboa: 1940, p. 77-80.

${ }^{26}$ Biblioteca Nacional do Rio de Janeiro. I - 47,5,8. CABRAL, Alfredo do Vale. Arte da língua brasílica. In: $O$ Globo. Rio de Janeiro: Páginas Bibliográficas do Jornal O Globo Impresso, 9 de novembro de 1875 ,

27 ABREU, João Capistrano de. Correspondência de Capistrano de Abreu. Rio de Janeiro: Ministério da Educação e Cultura, Instituto Nacional do Livro, 1954, vol. 2, p. 202.

${ }^{28}$ FREYRE, Francisco de Brito. Nova Lusitania: História da guerra brasilica. Lisboa: Joam Galram, 1675, p. 22.

${ }^{29}$ Biblioteca Nacional de Portugal (BNPT). RES. 243 P. [3], 91, [1] f. : il. ; 80 (15 cm). Fol. com erros.

${ }^{30}$ LESSA, Clado Ribeiro. As bibliotecas brasileiras dos tempos coloniais: apontamentos para um estudo histórico. In: Revista do Instituto Histórico e Geográfico Brasileiro, n. 191. Rio de Janeiro, 1946, p. 343. 
Da primeira edição são conhecidos, além do acima referido, mais dois exemplares. Há um no Instituto de Estudos Brasileiros da Universidade de São Paulo, na Coleção João Fernando de Almeida. Este, possivelmente, foi o que pertenceu à coleção do bibliófilo português João Nepomuceno, em fins do século XIX, que o descreve assim: "ARTE DA LINGUA BRASILICA, composta pelo Padre Luis Figueira da Companhia de Jesus, Theologo - segue uma vinheta com a divisa da Companhia -, Por baixo: Em Lisboa. Com licença dos Superiores. Por Manoel da Silva - In 8. de III-91-1 ff'. ${ }^{31}$ O terceiro exemplar está conservado na Biblioteca Nacional do Rio de Janeiro. Encadernado em pergaminho, foi adquirido por compra à Livraria Kosmos, naquela mesma cidade, em $1954 .{ }^{32}$

A Arte de Figueira foi o livro relacionado ao Brasil colonial que mais teve reedições entre os séculos XVII e XIX, totalizando, além da primeira, mais sete edições. A segunda edição saiu com o título mudado e com aditamentos feitos pelo padre Bartolomeu Leão, Arte de grammatica da lingua brasilica, em Lisboa, Officina de Miguel Deslandes, 1687; [8], 167, [1], em $8^{\circ}$. De uma suposta terceira edição publicada em Lisboa em 1754 não há exemplar conhecido e, para explicar esse desaparecimento, basta sublinhar que fora impressa no período da administração pombalina. A quarta edição foi publicada também em Lisboa por frei José Mariano da Conceição Vellozo (1742-1811), na Officina Patriarcal, em 1795; [4], 103, em 4. Há algumas indicações equivocadas de edições que nunca existiram em 1632, 1681 e $1714 .{ }^{33}$ Decerto, são conhecidas quatro edições no século XIX. A quinta edição, inçada de erros, foi publicada em Salvador em

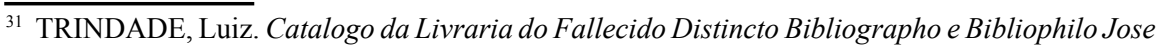
Maria Nepomuceno. Lisboa: Francisco Arthur da Silva, 1897, p. 92 e 93; item 711.

${ }^{32}$ MORAES, Rubem Borba de. Bibliographia brasiliana. Los Angeles: Ucla, 1983, vol. 1, p. 308. BNRJ, Cofre, 088,05,14, n. 5.

${ }^{33}$ SILVA Innocencio Francisco da. Diccionário bibliographico portuguez. Lisboa: Imprensa Nacional, 1860, vol. V, p. 286. "Arte da Grammatica da lingua brasileira. Lisboa, por Miguel Deslandes 1687. 8. de 68 pag. É segunda edição; a primeira, que parece viera á luz em 1621, é hoje raríssima, e della não vi até agora algum exemplar. O próprio Barbosa já no seu tempo ignorava até a existência della. (...) No Catalogo dos livros do Gabinete Português do Rio de Janeiro a pag. 117 encontro mencionada uma, que se diz quarta impressão d'esta Grammatica, com a indicação de Lisboa, 1714. Creio haver n'isto algum engano, que só poderá bem reconhecer-se á vista do respectivo exemplar". SILVA, João Manuel Pereira da. Os varões illustres do Brazil durante os tempos coloniaes. Paris: Livraria de A. Franck, 1858, Tomo 2, p. 352: "Luiz Figueira, Da lingua geral do Brazil, lisboa, 1632". p. 355 "Luiz Figueira, Arte da grammatica da lingua do Brazil, Lisboa, 1681”. SILVA, Innocencio da. Diccionário bibliográphico portuguez, vol III, p. 410, retruca o seguinte: "Creio poder afirmar com segurança, que jamais existiu a edição da Língua Geral do Brasil de 1632 mencionada nesta pag 352. A primeira edição que se fez da obra do P. Luis Figueira, cujo titulo integralmente restituído deve ser Arte da Grammatica da lingua do Brasil, diz-se ser de 1621; d'ella não vi comtudo até hoje algum exemplar". 
$1851 .^{34}$ A sexta foi feita em Leipzig em 1878 e a sétima no Rio de Janeiro em $1880 .{ }^{35}$ A oitava edição, Der Sprachstoff der brasilianischen Grammatik des Luis Figueira, foi publicada por Julius Platzmann em 1899. Os demais escritos de Luiz Figueira são bem conhecidos pelos historiadores. ${ }^{36}$

Mas voltando à questão de Capistrano de Abreu: "Que fim, porém, levou a primeira edição?” Para responder isso é necessário outra pergunta: em que ano foi, de facto, publicada a primeira edição? Essa questão até o presente permaneceu em aberto, visto que os três exemplares conhecidos não apresentam a data de publicação. Inocêncio Francisco da Silva, tomando a data da aprovação do padre Cardoso, 1620, sugere 1621 como o ano da sua publicação. Francisco Varnhagen, Francisco Rodrigues, Serafim Leite e Borba Moraes, seguindo Inocêncio da Silva, também assinalaram a data da primeira edição da Arte em $1621 .{ }^{37}$ Decerto não é possível indicar a data da primeira edição com precisão, mas pode-se afirmar, por duas razões, que não foi em 1621.

Primeiro, há uma questão a ser investigada: havia algum impressor com o nome de Manoel da Silva atuando em Lisboa no ano de 1621? A resposta é não. A referência mais antiga que a Biblioteca Nacional de Portugal (BNPT) registra de Manuel da Silva data de 1623, na obra Porta de linguas ou modo muito accommodado para as entender publicado primeiro com a tradução espanhola agora acrescentada a portuguesa, de Amaro de Roboredo, no qual Manuel da Silva aparece como livreiro, mas não editor, visto que esse livro saiu da oficina de Pedro Craesbeeck. Nele está impresso "vendese na Rua Nova na tenda de Manoel da Silva, 1623”. Deste modo, em 1623 ainda não havia em Lisboa um impressor chamado Manuel da Silva, mas um vendedor de livros que possuía uma tenda

${ }^{34}$ FIGUEIRA, Luís. Grammatica da lingua geral dos indios do Brasil, reimpressa pela primeira vez neste continente, depois de tão longo tempo de sua publicação em Lisboa, offerecida a Sua Magestade Imperial, por João Joaquim da Silva Guimarães. Bahia: Tvp. de Manuel Feliciano Sepúlveda, 1851.

${ }^{35}$ FIGUEIRA, Luís. Arte de grammatica da lingua brasilica. Reprodução fac-similar por J. Platzmann sob o título de Grammatica da lingua do Brasil. Leipzig: B. G. Teubner, 1878.

${ }^{36}$ FIGUEIRA, Luís. Relação de varios sucessos acontecidos no Maranhão e Grão Para, assim de paz como de guerra, contra o rebelde holandês, ingleses, e franceses e outras nações. Lisboa: Oficina de Mathias Rodrigues, 1631. Saiu anônimo: Memorial sobre as terras e gente do Maranhão \& Grão-Pará \& Rio das Almazonas. Lisboa: Oficina de Mathias Rodrigues, 1637. Publicado por Serafim Leite em 1940: Missão que Fes o P.Luiz Figueira da Companhia de Jesu, Superior da Rezidencia do Maranhão, indo ao Grã Parâ, Camutâ e Curupâ, Capitanias do Rio das Almazonas no Anno de 1636.

${ }^{37}$ VARNHAGEN, Francisco Adolfo de. Historia da paixão de Christo e taboa dos parentescos em língua tupi por Nicolas Yapuguay, com uma resenha dos impressos acerca da dita língua. Viena: Imp. I. e R. do Estado, 1876.,introd. XV p. 43. RODRIGUES, Francisco. História da Companhia de Jesus na Assistência de Portugal. Lisboa: 1931, tomo III, volume 1, p. 96. 
instalada na rua Nova. O auge das impressões feitas por Manuel da Silva ocorre entre os anos de 1639 e 1656, mas é possível que tivesse iniciado suas impressões entre 1627 ou 1628, utilizando os prelos de outras oficinas em Lisboa.

O mais antigo livro conservado pela BNPT que apresenta Manuel da Silva como impressor é a obra do arcediago Fernando Ximenes de Aragão, Restauracion del hombre y consolacion sobrenatural de la Theologia, "En Lisboa: por Manuel da Silva, 1628 (en Lisboa: en la emprenta de Gerardo de la Vinea, 1628)". O fato de este livro ter sido impresso na oficina de Geraldo da Vinha sugere que ainda naquele ano Manuel da Silva ensaiava suas primeiras impressões nas prensas de terceiros. Essa impressão, aliás, apresenta uma composição dos tipos superior à da Arte de Figueira.

\section{Figura 1 - Exemplar da BNPT da obra Restavracion del hombre.}

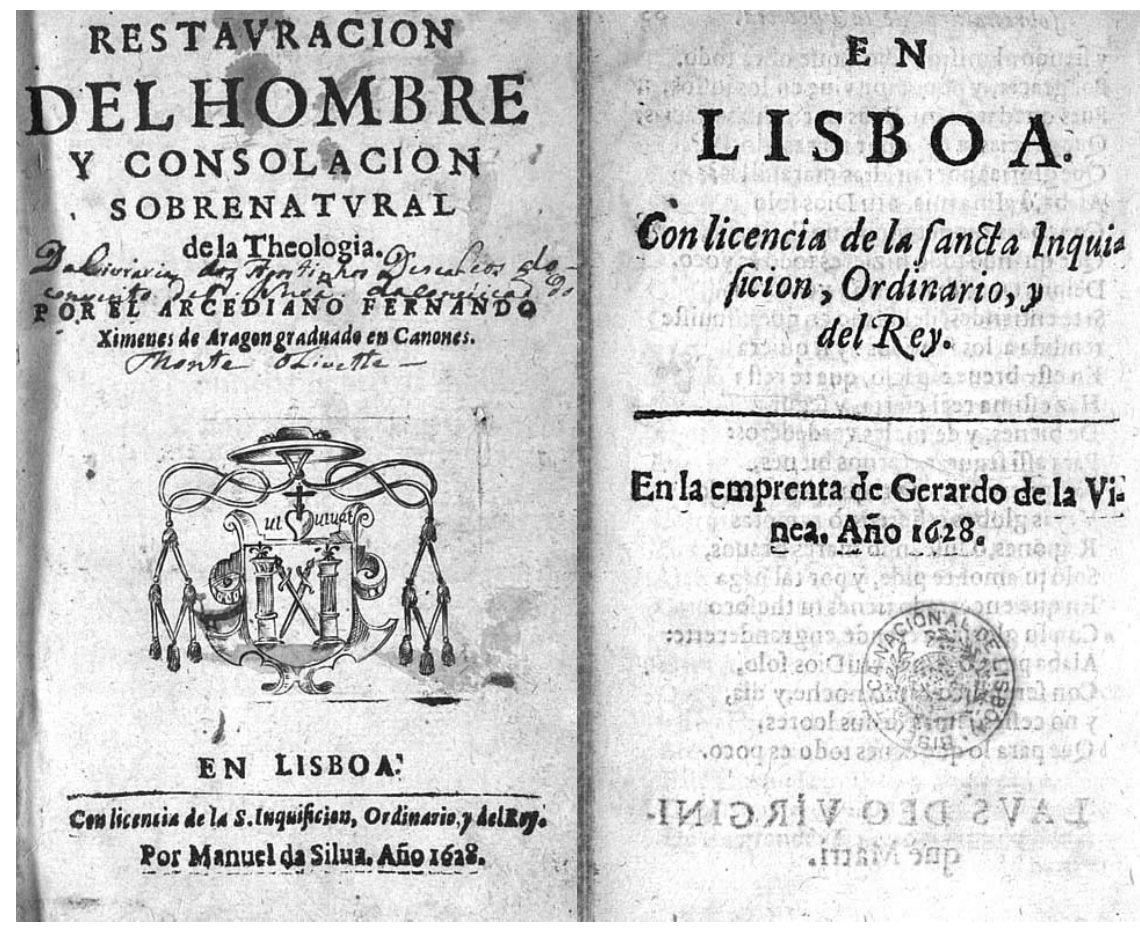


Em 1628, aparece, contudo, o primeiro livro, seguramente datado, impresso exclusivamente por "Emanuelem a Silva" que possui uma composição tipográfica tão amadora quanto a Arte de Figueira. Trata-se do livro de Garcia de Silva y Figueroa (1550-1624) Hispanicae Historiae Breviarium: ad illustrem, et generosum D. Don Vincentium Noguéram R. Pp. utriusque Signature Referendarium, Sacrarum Majestatum Caesareae \& Catholicae Consiliarium, Leopoldi Austriae Archiducis Cubicularium / autore illustrissimo, et generosissimo D. Don Garcia de Silva, \& Figueróa Philippi III Hispaniarum Monarchae Consiliario, eiusque ad Xaà Abbàs Persarum Regem Legato; ex Bibliotheca Noguerica nunc primùm edit Antonius Furtado de Rocha presbyter, eidem D. Don Vicentio a sacris. Olysippone: apud Emmanuelem a Silva, 1628. Há uma edição desta mesma obra com diferenças na página do título: Hispanicae Historiae Breviarium / autore illustrissimo, et generosissimo D. Don Gracia [sic] de Silva, \& Figueiróa Philippi III. Hispaniarum Monarchae Cõsiliario, eiusque adXaà Abbàs Persarum Regem Legato; nunc primum edit Antonius Furtado da Rocha. Olysippone: apud Emanuelem a Silva. Em nota, a BNPT afirma: "Posteriormente, saiu outra impressão com página de título diferente, sem dedicatória e sem data de edição". As indicações, não obstante, apontam o inverso, pois a edição sem data deve ser pouco anterior à datada de 1628, inclusive porque, na página de título, o nome "Gracia", que aparece na sem data, foi consertado por "Garcia" na edição datada.

\section{Figura 2 - Exemplar da BNPT da Hispanicae historiae breviarium.}

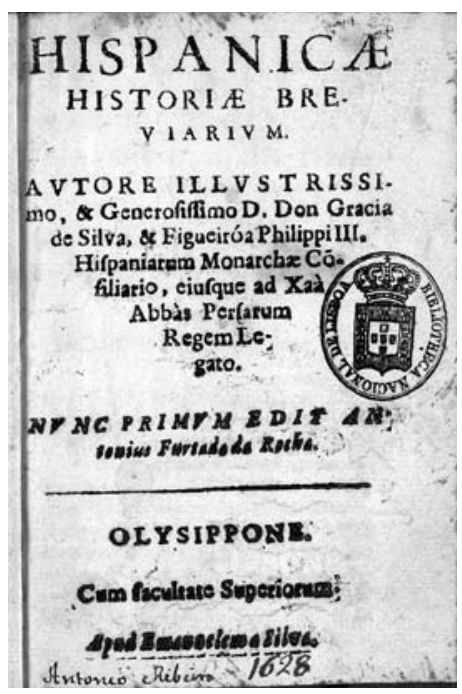


Deste modo, é desconhecida qualquer publicação feita pela oficina de Manuel da Silva antes de 1628. Observada a composição da página de rosto da Hispanicae Historiae Breviarium, ficaram perceptíveis algumas semelhanças, particularmente na primária disposição dos tipos, com a Arte de Figueira, indicando um impressor em início de carreira.

Em segundo lugar, uma carta autógrafa do padre Luiz Figueira, conservada no Cartório Jesuítico da Torre do Tombo e desconhecida pelo seu biógrafo, Serafim Leite, lança novas luzes sobre a origem da Arte da lingua brasilica. Vale transcrever o texto da missiva na íntegra:

Pax chri

Tenho particular consolação quando ouço boas nouas de VR refrescando sempre aquelle alegre tempo de minha entrada na Comp. ${ }^{\text {a }} \mathrm{E}$ do nouiciado no qual por meyo de VR. Nosso snõr me fes muitas merces; Seia o sõr seruido accrescentar a uida, E saude a VR in uiridi senectute. M. ${ }^{\text {tas }}$ ueses fallamos ca em V.R. os seus nouiços dos aques somos aqui tres ou quatro S. o P. ${ }^{\mathrm{e}} \mathrm{R}^{\text {tor }} \mathrm{Fr}^{\mathrm{co}}{ }^{\mathrm{c}}$ Frz, E o irmão Fr. ${ }^{\mathrm{co}}$ glz, E o irmão Rafael Cardoso. mas tambẽ V.R. se pode lembrar de quantas lagrimas chorei, quando V.R. nos deixou na prouação, E seia certo, que ainda ouje ouue em mim a mesma affeição. Mas reseruemos o perfeito gosto de repetir isto, pera o ceo, aonde o sõr nos aiunte, que ainda la me presarei de ser discipulo de V.R. $\mathrm{Na}$ sua me dis V.R. que não recebeo a minha, com a encomenda que mandei, E a uerdade he que não escreui, como tambem agora não escreui noutra occasião, em que mando outra pobre safinha (sic), em significação do animo agardecido, queira Ds chegue a saluam. ${ }^{\text {to }}$ que quando esta faço deue ir pello mar ia perto de $\mathrm{L}^{\mathrm{xa}}$.

Nouas minhas são ter saude e graças a Ds, E gabamo a V.R. de grande aldeão, porque anno, E meyo quasi residi agora nas aldeas dos Indios por seu cura tendo a minha conta mais de duas mil almas Em hũa aldea, E noutra quasi duas mil cuja lingoa estudei arresoadam. ${ }^{\text {te }} \mathrm{E}$ tenho feito hũa arte della com esperanças de se imprimir cedo. Seia so o sõr glorificado, que este he o meu intento, E tambem alegrar a V.R. Agora estou no coll. ${ }^{\circ}$ exercitando os ministerios nossos, Em casa $\mathrm{E}$ fora.

Temos prouincial o P. Simão Pinhr. ${ }^{\text {e }}$ que ia acabou tres annos, E espera por sucessor. R. ${ }^{\text {tor }}$ da Bahia he o P. ${ }^{\mathrm{e}} \mathrm{m} .^{\text {el }}$ Frz que pode ser tenha ia sucessor; mas nã no sabemos aqui. No rio de Janr. ${ }^{\circ}$ he R. ${ }^{\text {tor }}$ hũ $\mathrm{P}^{\mathrm{e}}$ natural de ca do Brasil por nome João d'oliua, $\mathrm{m} .^{\text {to }}$ honrado sogeito. La tem por subditos o $\mathrm{P}^{\mathrm{e}}{ }^{\mathrm{m}}{ }^{\mathrm{el}}{ }^{\mathrm{T}}$ Teno. ${ }^{\mathrm{o}}$ que foi seu antecessor sendo vicereitor E o P. ${ }^{\mathrm{e}}$ Gaspar da sylua que ueyo do reino, E outros dos companhr. ${ }^{\text {os }}$ do P. ${ }^{\mathrm{e}}$ Anriq Gomes, os quaes eu não conheço. $\mathrm{Na}$ Bahia le Theologia hũ $\mathrm{P}^{\mathrm{e}}$ Italiano. E o curso o $\mathrm{P}^{\mathrm{e}} \mathrm{m}^{\mathrm{el}}$ sanches, de grande habilidade. A minha missão do maranhão, pera a qual estou auisado ha tres, ou quatro annos, não acaba de se effeituar, eu estou prestes, ordene Ds o que for pera maior gloria sua, E sendo caso que V.R. ouça que uou, encomendeme $m .{ }^{\text {to }}$ a nosso sõr, porque terei grande necessid. ${ }^{e}$ pellas difficuldades, e trabalhos que a empresa promete. Sed non facio animam meam pretiosiorem quam me. Et nihil horum uereor. \& Crea V.R. que temos neste Brasil muito 
em que empregar os feruores dos nouiciados de Portugal: E que as ueses affracão algũs, que por uentura fasião mui afferuorados colloquios la nos presepios;

Finalmente eu me encomendo todo na benção de V.R. E em Seus Santos Sacrif. ${ }^{\text {ss }}$ offerecendome a tudo o que for de gosto de V.R. Deste Coll. ${ }^{\circ}$ de Pernambuco oje 10 de Nouembro de 621.

De V.R. f. ${ }^{o}$ em X. ${ }^{\circ}$ Luis Figr. ${ }^{\text {a }}{ }^{38}$

Essa carta revela, em primeiro lugar, os núcleos linguísticos que estudou para a composição do livro e para a elaboração do manuscrito da Arte. Uma das aldeias em que o "grande aldeão" escreveu sua Arte foi a da Apresentação de Nossa Senhora (ou Nossa Senhora da Escada) que os índios denominavam de "Aldeia de Caaeté", ou dos Caetés, às margens do rio Ipojuca, a 72 quilômetros de Olinda. ${ }^{39}$ Figueira seguiu para esse aldeamento em 1619, em companhia do padre Salvador da Silva e dos irmãos estudantes Manuel de Araújo e Antonio Caminha que aprendiam a língua tupi. Em 1621, o padre Belchior Pires tornou-se o superior de Nossa Senhora da Escada, tendo por companheiro o padre José da Costa. ${ }^{40}$ Assim, em princípios de 1621, Figueira seguiu para outro aldeamento. Mas qual? Não há indicação precisa na carta, mas possivelmente foi o de São Miguel de Muçuí, habitada por potiguares e tabajaras, que ficava a apenas 42 quilômetros de Olinda, sendo a mais próxima da de Escada.

Sabe-se, inclusive, que Luís Figueira e Francisco Pinto fizeram por terra, ao longo do ano de 1607, o mesmo roteiro que, no século anterior, haviam feito os índios caetés, que abandonaram o litoral após as guerras contra os portugueses. A estas aldeias de caetés e potiguares, pode-se somar a experiência de Figueira entre os tupinambás do Recôncavo baiano e, particularmente, do contato com os índios na missão até Ibiapaba. Assim, enquanto Anchieta sistematizou o falar que aprendeu dos guaianases ${ }^{41}$ tamoios e tupinambás, Figueira sistematizou sua gramática a partir da fala dos potiguares, tupinambás, tabajaras e caetés. Não havia outro jesu-

${ }^{38}$ Arquivo Nacional da Torre do Tombo. Cartório Jesuítico, maço 68, documento 390. Carta do padre Luiz Figueira. Colégio de Pernambuco, 10 de novembro de 1621.

${ }^{39}$ Os caetés eram um povo tupi-guarani que, no século XVI, habitava o litoral do Brasil entre a foz do rio São Francisco e a ilha de Itamaracá, na foz do rio Paraíba, numa área limitada, ao norte, pelas terras dos potiguaras e, ao sul, pelas dos tupinambás. Com a chegada dos europeus, muitos emigraram para o Pará.

${ }^{40}$ LEITE, Serafim. História da Companhia de Jesus no Brasil. Rio de Janeiro: Imprensa Nacional, 1945, vol. 5, p. 344.

${ }^{41}$ Os guaianases estendiam-se pelo litoral da Capitania de São Vicente, ocupando o território no trecho da costa de mais de 50 léguas entre Angra dos Reis e Cananeia, onde confinavam, ao norte, com os tamoios e, ao sul, com os carijós. 
íta mais apto a escrever uma gramática na língua geral do que Luis Figueira, visto que fora, até então, o único religioso português que travou contato com quase todos os povos indígenas que habitavam o Brasil desde a costa da Bahia até o Ceará.

A diferença entre as duas obras já desponta no estabelecimento de um alfabeto na língua geral. Pelas gramáticas de Anchieta e de Figueira, o alfabeto indígena compõe-se de todas as letras do português, menos F, L, S e Z; contudo o primeiro não utiliza o K, enquanto o segundo adotou o K. Os índios que habitavam o Brasil e o Maranhão não possuíam escrita e, por isso, cada gramático europeu procurou transcrever o tupi no alfabeto português, fazendo as devidas adaptações. Figueira também observou que os índios, muitas vezes, na mesma conversa, pronunciavam a mesma palavra com inflexões diferentes registrando que "os índios trocam as vezes algumas letras por mais delicadeza" de modo que parecem palavras diferentes, o que leva, quem apanha o dizer, não tendo o cuidado de distinguir, a escrever diferentemente do que ouviu antes. Portanto não é de se estranhar que uma palavra em tupi possa ser escrita de várias formas, por exemplo: Ygûasu, Yguassú, Yguaçú, Yguasú.

Outro ponto desmentido pela presente carta é o mito da Arte ter sido publicada em 1621, pois, em fins daquele ano, o manuscrito ainda estava com o seu autor, registrando que "tenho feito hũa arte della com esperanças de se imprimir cedo". A isto, segue a aspiração de que "Seia so o sõr glorificado, que este he o meu intento". Assim, em meados de novembro de 1621, Figueira, residindo em Olinda, ainda possuía a intenção de publicar a sua Arte. Comparados a Anchieta, que demorou quarenta anos entre a produção do manuscrito e a impressão, seis anos podem ser considerados "cedo".

Entre 1626 e fevereiro de 1627, frei Cristovão de Lisboa escreveu três cartas do Ceará para seu irmão, Manoel Severim de Faria, em Évora, criticando alguns livros que lhe chegaram às mãos. Nessas missivas, o franciscano atacou e elogiou Luís Figueira, afirmando que era o "melhor pregador do Maranhão", mas não menciona qualquer publicação do jesuíta. Na História do Brasil, concluída por volta de 1630, frei Vicente do Salvador afirma que era "Luiz Figueira, adornado de letras", indicando, por essa época, que o jesuíta já publicara algo, possivelmente referindo-se à Arte. ${ }^{42}$ Assim, é presumível que esta fosse ao prelo somente por volta de 1628, ocasião em que a oficina de Manoel de Silva já ensaiava suas primeiras publicações e ao tempo em que as missões no Maranhão já estavam sob a direção de Figueira.

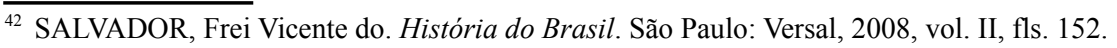


Figura 3 - Exemplar da BNPT da Arte da lingua brasilica.

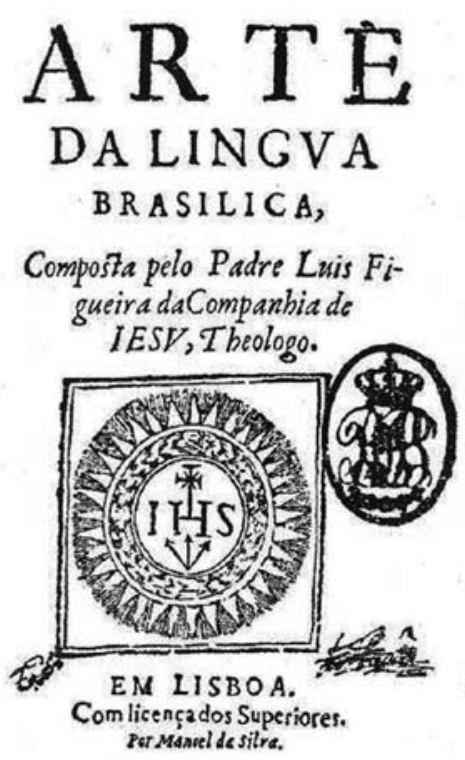

Há outras particularidades sobre a impressão da Arte. Para se imprimir um livro em Portugal, no século XVII, eram necessárias as licenças do Santo Ofício, do Ordinário e do Desembargo do Paço, os dois primeiros defendendo os interesses de setores da Igreja e o terceiro, do poder civil. Uma publicação dependia, portanto, dessas três licenças, que os tipógrafos da época, para sinalizálas, colocavam ao pé da folha de rosto "Com todas as licenças necessárias". Os autores que eram religiosos regulares precisavam receber, ainda, a licença de um superior da ordem ou da congregação. A Arte de Figueira recebeu apenas as "licenças dos superiores", conforme estampou na página de título, dadas por Manoel Cardoso. Assim, o livro não foi feito e não poderia ser comercializado; não era para o público; não deveria circular fora dos colégios do Brasil. Essa restrição à divulgação do livro teve razões de ordem política e estratégica.

Não há dúvidas de que, expulsos os franceses, a Companhia de Jesus estava se instrumentalizando para se estabelecer no Maranhão. No Ultramar, as gramáticas foram impressas em pares com os catecismos e, para facilitar a cristianização dos povos indígenas no Maranhão, foi publicado pelo jesuíta Antonio de Araújo o Catecismo da lingoa brasilica, no qual se contem a summa da doctrina christã, impresso em Lisboa por Pedro Craesbeeck no ano de 1618. Segundo seu autor assinalou, o objetivo do seu catecismo é para que os jesuítas "tenhao com que 
os possão perfeiçoar, \& reduzir os muitos [índios], que o novo descobrimento do Maranhão lhes está oferecendo". Ainda segundo ele, sua publicação se ordenou por via do reverendo padre provincial Pedro de Toledo (...) que o incumbiu de "se imprimir o catecismo, que nesta lingoa antigoamente composerao alguns Padres doctos, \& bons lingoas". ${ }^{43}$ Araújo, observou, ainda, a importância da comunicação entre os portugueses e os povos indígenas:

Pera que esta lengoa se aprenda, he mui importante a comunicação com aquelles, cuja lingoa se ha de aprender, \& escreverse nella, o que pode ajudar pera se alcançar, \& perfeiçoar sua sciencia, \& juntamente o que com elles se ha de exercitar, ou pera os reduzirem do mao estado, em que vivem, ou pêra os perfeiçoarem, no que forem achados.

Araújo cita, logo a seguir, no mesmo Prólogo do Catecismo, a Arte de Anchieta:

Pera a Companhia desta Provincia corresponder ao segundo de dar por escrito, o que julgou podia ajudar pera esta lingoa se saber, ja contribui o com este meyo, quando na era de $1595 \mathrm{fez}$ imprimir a arte da lingoa, com a qual seus filhos pudessem aperfeiçoar o que com o uso da comunicação com os Indios fossem aprendendo. ${ }^{44}$

Por volta de 1618, contudo, o conhecimento da língua geral apresentado na Arte de Anchieta estava "mui diminuto e confuso". Havia a necessidade de atualizar a composição da língua geral, pois que a gramática de Anchieta estava pronta desde 1556. Foi preciso, então, uma gramática nova, que mantivesse a estrutura da primitiva, mas que contemplasse uma língua que se transformava na medida em que os tupinambás migravam para as áreas ao norte da América portuguesa. Daí surge outra questão: quem financiou a impressão do Catecismo de Araújo e da Arte de Figueira? Como se pode ler no frontispício do Catecismo, sua impressão foi realizada "às custas dos padres do Brasil". Com a Arte não deve ter sido diferente, pois Figueira a dedica "Aos religiosos da Companhia de Jesus da provincia do Brasil". Ainda na dedicatória, assinala o "empenho do seu instituto", que pode ter custeado também essa publicação.

Mas o que pode explicar a suma raridade da primeira edição da Arte de Figueira? São conhecidos no presente, em bibliotecas brasileiras, americanas e europeias, doze exemplares da primeira edição da Arte de Anchieta e oito exemplares da obra Cultura e opulência no Brasil, do também jesuíta Giovanni

\footnotetext{
${ }^{43}$ ARAÚJO, Antonio de. O Catecismo da lingoa brasilica, no qual se contem a summa da doctrina christã. Lisboa: Pedro Craesbeeck, 1618, fls. 2.

${ }^{44}$ Idem.
} 
Antonio Andreoni, que teve a tiragem deliberadamente destruída pelo governo português. Do livro de Figueira existem apenas três exemplares, dois conservados no Brasil e um em Portugal, sendo que este pertenceu ao Colégio de Santo Alexandre. Não há, até o presente, qualquer registro de outro exemplar fora de bibliotecas lusófonas, indicando sua circulação na estrita esfera da congregação dos jesuítas brasílicos.

Diante do quadro de controle dessa publicação pelos jesuítas do Brasil, sabendo-se que não houve destruição deliberada da tiragem, há duas explicações para a existência de somente três exemplares da Arte de Figueira. Primeiro, devese considerar que a Arte não era um livro para ser conservado nas bibliotecas, antes sendo um instrumento de trabalho dos jesuítas. Para usar uma expressão contemporânea, a Arte era um livro didático utilizado pelos missionários que estavam aprendendo e ensinando o nheegatu (fala boa) e seus exemplares eram levados junto com eles para as diversas aldeias. Esse manuseio constante explicaria o desaparecimento de quase todos os exemplares.

Mudando o ano da publicação da Arte de 1621, como afirmavam Inocêncio, Francisco Rodrigues e Serafim Leite, para 1627 ou 1628, podemos deduzir algumas outras razões para esse virtual desaparecimento. Em 1621, Figueira ainda estava em Olinda, mas, a partir de março de 1622, estava em São Luís, para onde devem ter seguido a maioria dos exemplares da sua obra. O clima tropical, quente e úmido da região é pouco propício para conservar livros. Além disso, os jesuítas subiram o rio Amazonas e seguiram até o rio Tocantins, sendo que a zona equatorial proporciona o pior quadro possível para a conservação de livros. Mesmo com zelo, os exemplares da primeira edição podem ter sido destruídos pela umidade, por insetos ou pelas travessias de rios.

Há uma segunda hipótese para o desaparecimento da primeira edição da Arte. À época em que Figueira preparava-se para retornar ao Maranhão, em companhia do governador Pedro Albuquerque, redigiu uma carta em que afirmou que os missionários estavam prontos para a viagem, fazendo alusão ao seu trabalho nas missões e ao seu conhecimento da língua dos índios do Brasil, dizendo que "compos, e imprimio hũa Arte da mesma lingoa". ${ }^{45}$ Esse manuscrito teria sido comprado pelo historiador brasileiro Clado Ribeiro Lessa. Serafim Leite teve notícia dessa carta, mas não a utilizou na biografia de Figueira e atualmente é desconhecido o local onde está conservada. ${ }^{46}$

\footnotetext{
${ }^{45}$ Bibliografia americana: catalogo de alguns livros e manuscriptos raros e curiosos, principalmente sobre o Brasil (Catálogo ${ }^{\circ}$ 14). Lisboa: Livraria Coelho, 1930, p. 134, item $\mathrm{n}^{\circ} 1.084$.

${ }^{46}$ LEITE, Serafim. História da Companhia de Jesus no Brasil, op. cit., vol. 8, p. 240. A carta de Fi-
} 
Por que Figueira faria menção à sua Arte numa carta escrita por volta de 1643? Estaria transportando os exemplares na malograda navegação para Belém naquele ano? Sem a leitura do manuscrito na íntegra é impossível responder a essas questões.

O fato é que, mesmo após a morte de Figueira e seus confrades em 1643, sua Arte da lingua brasilica continuou uma ferramenta estratégica para as missões jesuíticas no Estado do Maranhão, que foram retomadas em 1652 sob a direção de Antonio Vieira, acompanhado por 23 religiosos da sua congregação. Ao receber essa missão Vieira afirmou que "a cultura de toda esta grande messe nos está encarregada por S. Magestade (...) e aceitamos toda, porque assim se supõe ao princípio e assim o fez o Padre Luiz Figueira". ${ }^{47}$ Vieira mandou que fossem criadas duas classes, uma para ensinar crianças a ler, escrever e contar, e outra de gramática, mas "na terra não havião os intrumentos necessários para o exercicio dos novos estudos", cabendo ao próprio superior da missão providenciar para os estudantes "artes, cartapacios e papel". ${ }^{48}$

Em 1654, o padre Manoel Teixeira, cônego da Sé de Elvas e vigário de Belém, afirma que havia mais de quatrocentas aldeias na região, "ou para melhor dizer cidades muito populosas", sendo que algumas contavam cinco ou seis mil flecheiros, fora velhos, mulheres e crianças, e que os jesuítas se dedicavam aos estudos das línguas indígenas o dia inteiro e até mesmo durante a noite. ${ }^{49} \mathrm{~A}$ falta de domínio da língua geral pelos jesuítas que chegavam da Europa atrasava o processo de catequização dos povos naquele vasto território. Isto, segundo Vieira, era um grave problema para o desenvolvimento das missões:

Aos padres do Pará se mandou já uma cópia dos catecismos, porque a não puderam levar quando foram, e, como são ainda pouco práticos na língua, servir-lhes-ão muito para as doutrinas, que sem embargo disso também fazem..$^{50}$

Por chefiar um grupo de recém-chegados de Portugal e inexperientes em relação à língua geral, Vieira sugeriu ao geral Gosvínio Nickel que lhes fossem enviados "sujeitos do Brasil práticos na língua", alegando que "os Colégios do

gueira não foi encontrada no espólio da coleção Ribeiro Lessa, leiloada no Rio de Janeiro em 2007.

${ }^{47}$ LEITE, Serafim (ed.). Novas cartas jesuíticas: de Nóbrega a Vieira. São Paulo: Companhia Editora Nacional, 1940, p. 254.

${ }^{48}$ MORAES, Jose de. Historia da Companhia de Jesus na extincta provincia do Maranhão e Pará. Rio de Janeiro: Typ. Do Commercio, de Brito \& Braga, 1860, p. 269.

${ }^{49}$ Ibidem, p. 302-307.

${ }^{50}$ AZEVEDO, João Lúcio de (ed.). Cartas do padre Antonio Vieira. Coimbra: Imprensa da Universidade, 1925, vol. 1, p. 340. 
Brasil são em tudo como os da Europa e os índios e as missões estão lá quase acabados, e ainda insgines na língua são muitos". ${ }^{51}$ Vieira apresentou uma lista de religiosos que solicitaram para ir do Brasil ao Maranhão, dentre os quais estavam Francisco Pais, Francisco de Avelar, Francisco Madeira, Manuel Ribeiro, Francisco de Morais, Manuel Pedroso, Antonio de Mariz, Paulo da Costa, Francisco Ribeiro, Domingos de Abreu, João Pereira e Gaspar de Araujo, todos com pleno domínio da língua geral.

Além disso, Vieira reconheceu que os religiosos do Brasil não seriam suficientes e pediu a criação de um noviciato no Maranhão, afirmando, em setembro de 1658, que para tal faltava apenas a licença do geral Gosvínio Nickel. ${ }^{52}$ A primeira das razões para estabelecer um noviciato, aponta Vieira a Nickel, em carta do rio Amazonas, a 21 de março de 1661, era a "necessidade de se apreenderem as línguas". O jesuíta afirmou que era necessário educar os meninos no nheegatu e português ainda na infância

a qual idade é a que mais serve, porque se acomodam ao clima, aos mantimentos e aos costumes da terra, aprendem, e tomam as línguas com grande facilidade, e as pronunciam com toda a perfeição, o que raramente fazem os que vem de maior idade, como se tem experimentado no Província do Brasil, em que dos que vieram de Portugal com estudos acabados, nenhum houve que soubesse a língua da terra. ${ }^{53}$

Noutra carta escrita três dias depois, Vieira ilustra sua afirmação tomando, com ironia, o caso de um missionário italiano chamado Giovanni Maria Garzoni que, então, não compreendia a língua geral e apresentava dificuldades até mesmo na língua portuguesa:

Dei-lhe também o método que havia de seguir, em apreender e estudar a língua, com que se não conformou, e dizendo-me que a razão de não apreender, era a ocupação da Aldeia e não ter mestre (sendo que o melhor mestre é a mesma ocupação, e trato com os índios), tirei-o da Aldeia e pu-lo na casa, desocupando-o de tudo, e lhe dei por mestre o irmão mais perito na língua e na gramática dela. ${ }^{54}$

Seria o método que Vieira deu ao padre Garzoni um exemplar da primeira edição da Arte de Luís Figueira? É possível que sim porque, além da Arte de Anchieta, não havia outra disponível. O fato é que o empenho de Vieira em relação

\footnotetext{
${ }^{51}$ LEITE, Serafim (ed.). Novas cartas jesuiticas, op. cit., p. 272.

52 Ibidem, p. 275.

53 Ibidem, p. 274 e 292.

${ }^{54}$ Ibidem, p. 299.
} 
ao italiano deu os frutos que esperava e Garzoni tornou-se um dos "línguas" mais ativos do Maranhão e Grão-Pará até princípios do século XVIII.

Em 1660, enquanto esperava o navio para o Maranhão, João Felippe Betendorff fez uma tradução resumida em latim de um exemplar da Arte da lingua brasilica que encontrou em Lisboa, pois que, segundo o próprio missionário, "verti em língua latina toda a Arte brasilica, [de maneira] breve mas clara". Tradução pensada para facilitar o aprendizado de jesuítas de outras nações europeias, visto que religiosos da província galo-belga e da Itália, que seguiram para o Maranhão, estavam mais acostumados com a língua oficial da Igreja do que com a língua portuguesa. Mais de três décadas após sua publicação, a Arte de Figueira continuava uma ferramenta necessária para as missões, ainda que, como era comum a outras gramáticas da época, corresse manuscrita entre os missionários, sendo alterada ou complementada para atender a diglossia das línguas indígenas. ${ }^{56}$ A Biblioteca da Universidade de Coimbra guarda o manuscrito de uma Gramatica da lingua geral do Brazil, feita no Pará em 1750, que conserva elementos da Arte de Figueira. ${ }^{57}$

O jesuíta José de Moraes afirmou, no século XVIII, que a Arte de Figueira era "uma chave mestra, com que pudessem abrir as portas, à maior dificuldade dos mistérios, que era a instrução dos adultos". ${ }^{58}$ Além disto, Moraes asseverou que essa obra era "de composição tão perfeita, e tão delicada nos preceitos das suas regras, que nenhum dos muitos Missionários que ha e tem havido lhe tem até o dia de hoje descoberto o menor defeito, ou julgue necessitar de maior aumento, cousa rara no mundo na composição de artes". ${ }^{59}$

Por volta de 1680, os exemplares da Arte já deviam ser tão escassos que o padre João Felippe Bettendorf organizou a segunda edição para dar continuidade aos trabalhos missionários no Maranhão. Esse jesuíta afirmou, em sua Crônica dos padres da Companhia de Jesus no Estado do Maranhão, que Figueira "por

${ }_{55}^{5}$ LEITE, Serafim. História da Companhia de Jesus Brasil, op, cit., vol. 8, p. 101.

${ }^{56}$ BARROS, Maria Cândida Drumond Mendes. A relação entre manuscritos e impressos em tupi como forma de estudo da política linguística jesuítica no século XVIII na Amazônia. In: Revista Letras, n. 61, Especial, p. 125-152, Curitiba, 2003.

${ }^{57}$ Biblioteca da Universidade de Coimbra. Ms. 69. Gramatica da lingua geral do Brazil, com hum Diccionario dos vocabulos mais uzuaes para a intelligencia da dita lingua. [Pará: 1750]. [1], [3] f. [1 br.] [1] f., 224 p. [2] f., [4 br.], [86] f., [3 br.], [1] f. Disponível em: URL: http://bdigital. sib.uc.pt/bg3/UCBG-Ms-69/UCBG-Ms-69 item1/index.html >. Acesso em 5 set 2010.

${ }_{58}$ MORAES, Jose de. Historia da Companhia de Jesus na extincta provincia do Maranhão e Pará, op. cit., p. 134.

${ }^{59}$ Ibidem, p. 221. 
puro zelo da salvação das almas compoz a Arte da lingua brazilica".${ }^{60}$ A Arte da lingua brasilica, não obstante, estava inserida em um projeto ultramarino que alinhava a criação de um sistema defensivo com baixo custo e capaz de repelir as incursões militares de outras nações europeias, utilizando um sistema de aldeias que bloqueavam o acesso de forças estrangeiras ao território português. No Maranhão, a chave desse sistema estava nos padres da Companhia de Jesus e nos missionários de outras ordens que doutrinavam os povos indígenas locais. Assim, nas palavras do padre João Daniel, a história da Arte de Figueira confunde-se com a própria história das guerras no Maranhão na primeira metade do século XVII:

E nas guerras contra os holandeses, [os indígenas] tem ajudado muito os portugueses, assim eles se não fossem acabando; porque já não existem, nem a redízima. Por ser tão estendida, e numerosa esta nação [tupinambá] e com elas se fundarem as primeiras missões sendo a sua lingoagem a mais difusa, e geral, se resolveram os missionários a reduzi-la a arte como fizeram no Brasil o venerável Padre José de Anchieta, e no Pará, e Maranhão o Padre Luís Figueira, ambos jesuítas, cujas artes são, e tem sido ategora as que se usam em todas as missões. (...) E posto que haja outras nações de diverso idioma, e sem uso desta lingoa geral, descendo para as missões logo com os mais a aprendem. ${ }^{61}$

\section{A guerra pela gramática brasílica}

Uma característica da primeira edição da Arte, conforme observado acima, foi a sua circulação restrita à congregação dos jesuítas. E não faltaram razões para o conteúdo desse livro correr num círculo restrito. A primeira edição foi publicada no período em que Castela estava em guerra contra as Províncias Unidas e os neerlandeses não tardaram a perceber a importância de compreender as línguas dos povos índigenas para estabelecer o domínio político na América portuguesa. Para isso, tentaram, por diversos meios, aprender e divulgar as línguas usadas no Brasil e no Maranhão.

Segundo uma relação do capitão André Pereira, o capitão-mor do GrãoPará, Francisco Caldeira, informou que, entre os índios que ele persuadira a se estabelecer à roda de Belém, encontrara um francês e um holandês. Essa dupla afirmou a Caldeira que aguardava uma expedição da Holanda com quinze navios

${ }^{60}$ BETTENDORF, João Felipe. Crônica da missão dos padres da companhia de Jesus no Estado do Maranhão. In: Revista do Instituto Histórico e Geográfico Brasileiro, t. 72, v. 119. Rio de Janeiro, 1909, p. 66.

${ }^{61}$ DANIEL, João. Tesouro descoberto no rio Amazonas (séc. XVIII). Rio de Janeiro: Biblioteca Nacional, 1976, vol. 1, p. 269. 
para fundar colônias naquela região e "que dois anos antes haviam sido deixados entre os indígenas, para lhes apreenderem a língua”. Apesar desse plano para aprender a linguagem dos povos que habitavam o Maranhão ter sido interceptado, a notícia de que os neerlandeses estavam infiltrados no Pará com o objetivo de apreender as línguas indígenas deixou alarmado o arcebispo de Lisboa, dom Afonso Furtado de Mendonça, que, no Conselho de Portugal, informou ao governador d. Luís da Silva, em carta datada de 4 de dezembro de 1616, para que reforçasse as defesas sob sua jurisdição. ${ }^{62} \mathrm{~A}$ interceptação do holandês atrasou os planos das Províncias Unidas em utilizar a língua geral.

O projeto dos neerlandeses de conquistar territórios na América portuguesa ganhou força em 1621 com a criação da Companhia das Índias Ocidentais (WIC) que se aliou aos Estados Gerais em 1623 para atacar o Recôncavo baiano. A conquista de Salvador (1624-1625), entretanto, foi um desastre para a WIC, em grande medida por desconhecerem a língua dos tupinambás, o que impediu qualquer possibilidade de aliança com esses indígenas. ${ }^{63}$ Foi nesse episódio que

Os diretores da Companhia das Índias perceberam com clareza o perigo que os jesuítas representavam para a estabilidade do domínio holandês, em especial por causa de sua influência sobre os índios. Companhia das Índias e Companhia de Jesus eram instituições rivais que não poderiam ocupar o mesmo espaço. Assim o entendiam os diretores da WIC e as autoridades da própria Companhia de Jesus. ${ }^{64}$

Após o fracasso no Recôncavo em 1625, a armada de Boudewijn Hendrikszoon, para fugir da armada luso-espanhola que reconquistara Salvador, rumou em direção à baía da Traição, onde estabeleceu contato com potiguares, levando para as Províncias Unidas seis homens deste povo, incluído Gaspar Paraupaba e Pedro Poti. Os neerlandeses os educaram em sua língua e costume, mas não há registro de que tenham se preocupado em decodificar sua língua.

Durante a guerra de conquista de Pernambuco e das capitanias do Norte (1630-1637), um grupo de intelectuais neerlandeses, ligados em maior ou menor medida à Companhia das Índias Ocidentais, iniciou ações para aprender a

${ }^{62}$ Relaçam do que ha no grande Rio das Amazonas novamente descuberto. In: Annaes da Bibliotheca Nacional. Rio de Janeiro: Officina da Bibliotheca Nacional, vol. XXVI, 1904, p. 256-257. SOUTHEY, Robert. História do Brasil (1810). São Paulo: Editora Obelisco, 1965, vol. 2, p. 83.

${ }^{63}$ PARAÍSO, Maria Hilda; MAGALHÃES, Pablo Iglesias. Muros do Recôncavo: transferência da capital da América portuguesa para os aldeamentos jesuíticos (1624-1625). In: Clio. Dôssie História Indígena. UFPE, 2007, v. 25-2, p. 9-38.

${ }^{64}$ VAINFAS, Ronaldo. O plano para o bom governo dos índios: um jesuíta a serviço da evangelização calvinista no Brasil holandês. In: Clio Revista de Pesquisa Histórica. UFPE, 2009, v. 27-2, p. 153. 
gramática e o vocabulário das línguas indígenas, com o objetivo de consolidar o projeto de consquistar os territórios do Brasil e do Maranhão. Em 1631, o conselho político que governava a guerra no Brasil enviou uma expedição com dois navios ao Rio Grande e Ceará para formar uma aliança com Nhanduí e Oquenou, os principais daquelas capitanias. Chefiava essa expedição o capitão Elbert Smient, que contava com quatro índios tradutores, Marcial, Andries Tacon, Ararova e Francisco Matauve. Essa embaixada, no entanto, fracassou. ${ }^{65}$

O fato é que, até 1633, os neerlandeses não haviam decodificado a língua geral, considerada por Gaspar Barleu como "difícil de aprender". ${ }^{66}$ A balança linguística, ironicamente, equilibrou-se em decorrência do sucessor do padre Luís Figueira nos aldeamentos de São Miguel de Muçuí, o então jesuíta Manoel de Moraes, que se aliou aos neerlandeses em $1634 .{ }^{67} \mathrm{Em} \mathrm{1635,} \mathrm{Moraes} \mathrm{seguiu} \mathrm{para}$ Amsterdã, onde se aproximou de Johannes de Laet, um dos principais intelectuais daquele período e um dos Heeren XIX (dezenove senhores). O ex-jesuíta apresentou à WIC o Plano para o bom governo dos índios, projeto que passaria pelo domínio da língua geral pelos missionários calvinistas ligados à empresa no Brasil. Segundo Ronaldo Vainfas

O Plano também estabelecia que os predicantes deveriam aprender a língua dos índios, sublinhando que a catequese calvinista deveria concentrar seu foco nas crianças. $O$ fato é que seu Plano foi adotado em diversos pontos essenciais: a preparação de tradutores; (...) Mas a adaptação do modelo jesuítico para a evangelização calvinista teve sucesso limitado. Encontrou dificuldades no campo linguístico e se viu muito afetada pelas divergências entre ministros e predicantes. ${ }^{68}$

Na sua privilegiada posição na diretoria da Companhia das Índias Ocidentais, Johannes de Laet tivera acesso irrestrito ao grande volume de informações que seguiam do Brasil holandês para Amsterdã. Não surpreende que a primeira gramática da língua geral, impressa fora de Portugal, tenha sido publicada, em resumo, por Johannes de Laet em 1643, quando buscou, nos elementos filológicos, os fudamentos para contestar a tese do jurista Hugo Grotius acerca das

${ }^{65}$ MELLO, José Antonio Gonsalves de. Templo dos flamengos. Rio de Janeiro: Topbooks, 2004, p. 208; SCHALKWIJK, Frans Leonard. A Igreja e o Estado no Brasil holandês (1630-1654). São Paulo: Cultura Cristã, 2004, p. 208 e 209.

${ }^{66}$ BARLEU, Gaspar. História dos feitos recentemente praticados durante oito anos no Brasil (1647). Rio de Janeiro: Ministério da Educação, 1940, p. 22.

${ }^{67}$ VAINFAS, Ronaldo. Traição: Um jesuita a serviço do Brasil holandês processado pela Inquisição. São Paulo: Companhia das Letras, 2008, p. 72-73.

${ }^{68}$ VAINFAS. O plano, op. cit., p. 158-159. 
origens dos povos americanos. A Arte da lingua mais falada na costa do Brasil foi resumida por Laet no Appendix das Notae ad Dissertationem Hugonis Grotii De Origine Gentium Americanarum. Laet não conheceu a Arte de Figueira, mas a "Gramaticam integram edidit P. Iosephus Anchieta Provincialis Societatis Iesu Brasilia. Conymbricae, 1595". ${ }^{69}$ Além disso, Laet publicou, na mesma obra, um vocabulário da "Brasilianorum lingua", da autoria de Manoel de Moraes. ${ }^{70} \mathrm{O}$ sucesso da Notae ad Dissertationem de Laet foi imediato, sendo publicado em Paris no mesmo ano e tendo segunda edição em Amsterdã no ano de 1644.

Johannes de Laet foi, contudo, um letrado de gabinete e o vocabulário básico junto com seu resumo da gramática de Anchieta de pouca serventia teria para quem desejasse a fluência da língua geral. O mesmo pode ser dito da obra do naturalista Georg Marggraf, Historiae rerum naturalium Brasiliae, publicada em Amsterdã no ano de 1648. Johannes de Laet também incluiu nesse livro, visto que Marggraf já havia morrido, outro resumo de Da lingua brasiliensium, è grammatica P. Josephi de Anchieta, S.I. contendo um sumário sobre a fonética tupi e as partes da oração. ${ }^{71}$ Laet inseriu, nesse livro, outra vez, o Dictionariolum nominum \& verborum linguae Brasiliensibus maxime communis e o Dictionariolum verborum maxime communium, de autoria do ex-jesuíta Manoel de Moraes, listando 153 vocábulos, entre substantivos e adjetivos, e 137 verbos mais comuns utilizados pelos índios, com os seus equivalentes latinos. ${ }^{72} \mathrm{Nem}$ Johannes de Laet, Georg Marggraf ou mesmo Manoel de Moraes parecem ter conhecido a Arte de Figueira, visto que o primeiro reproduziu em duas ocasiões, 1643 e 1648, os resumos da Arte de Anchieta.

Num livro publicado em 1651, um dos intérpretes mais ativos do Brasil holandês, o francês Pierre Moreau, além de atribuir aos jesuítas a primazia na criação de um sistema gramático e de dicção que deu origem à língua geral, afirmou que os missionários neerlandeses copiaram esse sistema com o objetivo de evangelizar os índios "nessa mesma língua":

Os jesuítas são louváveis por terem organizado uma ortografia que exprima todas as palavras e dicções de sua língua, muito próxima da pronúncia nativa, em letras de nossos caracteres, e foram os primeiros que os ensinaram a ler e escrever. Os holandeses, depois,

\footnotetext{
${ }^{69}$ LAET, Johannes de. Notce ad Dissertationem Hugonis Grotii De Origine Gentium Americanarum et Observationes aliquot ad meliorem indaginem difficillimce illius Qucestionis. Amsterdã: Ludovicum Elzevirium, 1643, p. 219-223.

${ }^{70}$ Ibidem, p. 181-185.

${ }^{71}$ MARGGRAF, Georg. Historiae rerum naturalium Brasilice, libri octo. Amsterdam \& Leyden: François Haack and Louis Elsevier, [1648], p. 274-275.

${ }^{72}$ Ibidem, p. 276-277. VAINFAS. Traição, op. cit., p. 127.
} 
também sempre mantiveram pregadores e mestre-escolas para evangelizá-los e ensinarlhes a religião cristã nessa mesma língua. ${ }^{73}$

Havia, não obstante, um missionário que estava a serviço da Companhia das Índias Ocidentais e que poderia concorrer com os melhores linguistas da Companhia de Jesus na América portuguesa, inluíndo nesse rol Anchieta e Figueira. Segundo Moreau

Mas de todos quem merece os maiores elogios, por ter conseguido os melhores resultados, foi um jovem ministro inglês que foi criado, como os seus outros colegas, especialmente entre eles desde a idade de seis até quatorze ou quinze anos, quando foi enviado à Universidade de Leiden, onde estudou um tempo e se tornou teólogo; voltou ao Brasil e depois de seu retorno a esses povos traduziu-lhes o Velho e o Novo Testamentos, do texto original para a língua brasiliana, com o que eles testemunharam maravilhosa alegria, pois desse modo entendem inteiramente a história santa, desconhecida de todos os seus antepassados e entregam-se com prazer à sua leitura e a ouvi-la. ${ }^{74}$

Quem era esse jovem inglês criado entre os índios dos seis aos quatorze anos? De saída, podemos indicar três nomes: Thomas Kemp, Johannes Eduardus e Johannes Apricius. Thomas Kemp era inglês, mas, por volta de 1645, já não era mais tão jovem, visto que viera para o Brasil desde 1630; Johannes Eduardus, não era inglês, mas nascido na Zelândia (Seelandus), e retornara para a Europa em 1643, dois antes de Pierre Moreau vir para o Brasil e, portanto, não o conheceu. ${ }^{75}$ Sobra Johannes Apricius ou, em inglês, John Price. Era jovem em 1645, visto que Johan Nieuhof afirmou que "o noviço Johannes Apricius" destacou-se "na catequese dos infiéis". ${ }^{76}$

Apricius chegou ao Brasil holandês como soldado de Groningen e serviu como professor na missão do reverendo Thomas Kemps na Paraíba em 1644, vivendo no período turbulento da Guerra de Restauração (1645-1654). Em maio de 1645, o diretor da WIC em Itamaracá, Dortmont, avisou ao Alto Conselho do Recife que os índios "haviam retirado para as matas, recusando-se a se reunir novamente à nossa tropa". Apricius foi enviado para aquela capitania e

${ }^{73}$ MOREAU, Pierre. Histoire des derniers troubles du Bresil entre les hollandois et les portugais. Paris: Chez Augustin Courbe, 1651, p. 204-205.

${ }^{74}$ Idem.

${ }^{75}$ HOTTINGE, Johann Heinrich. Archaiología Orientalis exhibens, II Topographia Ecclesiastica, cap. III. Heildeberg: Typis Samuelis Broun, 1662, p. 48.

${ }^{76}$ NIEUHOF, Johannes. Memorável viagem maritima e terrestre ao Brasil. São Paulo: Itatiaia, 1981, p. 353. 
"conseguiu ele com sua argumentação demover 25 amotinados (...) trazendo-os pacificamente de volta". ${ }^{77}$

Por conta da guerra, Apricius travou contato com quase todos os povos indígenas que Luís Figueira havia conhecido para redigir sua Arte três décadas antes. Além da Paraíba e de Itamaracá, Apricius esteve na ilha de Itaparica, no Recôncavo baiano, quando Sigsmund Von Schkoppe estabeleceu uma base neerlandesa na Ponta das Baleias em fevereiro de $1647 .{ }^{78}$ Nessa missão, Schkoppe levou consigo 297 potiguares da Paraíba. De Itaparica, Johannes Apricius seguiu para o Recife, onde foi examinado, no dia 8 de agosto do ano 1647, pelos deputados da classe, na presença do senhor Jacob Airichs como presbítero, sendo promovido ao Ministério. ${ }^{79} \mathrm{Na}$ sua ação missionária na Paraíba conviveu com potiguares, em Itaparica deve ter contatado os tupinambás e no Recife pode ter conhecido tabajaras. Somente não esteve na Capitania Ceará, pois, deste modo, completaria o circuito percorrido por Figueira antes de 1622.

A primeira tentativa de organizar uma gramática tupi nas Províncias Unidas partiu, assim, do reverendo Johannes Apricius. Após seu retorno para a Holanda, apresentou-se ao Presbitério de Amsterdã em 1657, entregando um Dicionarium Brasilicum Belgicum, ocasião em que prometeu levar uma gramática tupi e o $C a$ tecismo de Heildeberg tupi-holandês, "esperando que de vez em quando pudesse ter a sua utilidade". ${ }^{80}$ Em 1676, encontramos a notícia de que John Price, pastor da Igreja inglesa de Haia, foi nomeado governador de "Wiapoco" (Oiapoque) ${ }^{81}$

Quando fez a promessa de entregar suas três obras ao Presbitério de Amsterdã, os neerlandeses já haviam sido expulsos do Brasil há três anos. O projeto de um Brasil holandês estava encerrado. Não houvera mais, então, objetivos políticos

${ }^{77}$ Ibidem, p. 280.

${ }^{78}$ IAGHP. Instituto Arqueológico Geográfico e Histórico de Pernambuco. Coleção José Higino. Brieven en Papieren uit Brazilië (Cartas e papéis do Brasil, cópia do século XIX) 1647|14. Carta de Schkoppe ao Alto Conselho do Recife.

${ }^{79}$ SCHALKWIJK, Frans Leonard (ed.). A Igreja cristã reformada no Brasil holandês. Atas de 1636 a 1648. In: Revista do Instituto Arqueológico, Histórico e Geográfico de Pernambuco, LVIII. Recife, 1993, vol. 58-60, p. 274.

${ }^{80}$ Gemeente-Archief Amsterdam (Arquivo da Cidade de Amsterdam), Archief Classis Amsterdam (Arquivo do Presbitério de Amsterdam), vol. 6 (1656-1670), 12 de julho de 1657, fl. 59.

${ }^{81}$ HARTSINCK, Jan Jacob. Beschryving van Guiana, of de Wilde Kust in Zuid-America. Amsterdam: Gerrit Tielenburg, 1770, vol. 2, p. 923. "Ondertusschen werd Johannes Price a Apricius, Predikant der Engelsche Gemmente te's Gravenhage, tot Gouverneur van de Colonie op Wiapoco by Kaap Oranje aangesteld, habbende zyn Eed, voor welgemelde Collegie, op. den 3. den December 1676, afgelegt". É da autoria de Apricius o seguinte opúsculo: Een kort en bondigh Vertoogh van de considerable Colonie, die de ... Staten van Hollandt .... hebben goedt-gevonden ende geresolveert .... uyt te setten op de vaste Kuste van America, vervattende bet fundament tot beter establissement, bevolckinghe en bescherminge van dien; de favorable conditien enz. Gravhagen: J. Scheltus, 1676. 
para a publicação de seus três manuscritos, que não foram localizados nas pesquisas efetuadas por José Higino Pereira ou por Frans Leonard Schalkwijk. Assim, é possível que Apricius nunca tenha redigido sua gramática tupi. Na corrida pela codificação da língua geral, os gramáticos neerlandeses saíram com um século de atraso. Esse atraso lhes custou a criação de uma linha defensiva no Ceará utilizando uma rede de aldeias da região. Em 1638, o Alto Conselho do Recife informou que

Os brasileiros do Maranhão, morando agora no Camassi, aonde eles construíram sua Aldeia, que mandaram seus representantes, para fazer conosco uma aliança e construir laços de amizade, dizendo que se nós quisermos entrar em guerra em Maranhão eles não estarão contra nós, mas ao contrario nos ajudarão de todas as maneiras possíveis contra os portugueses. ${ }^{82}$

A atuação dos jesuítas chefiados por Luís Figueira, pelo contrário, definiu os contornos das guerras no Maranhão. Em 1637, a Companhia das Índias Ocidentais conquistou a Capitania do Ceará que, então, situava-se no Estado do Maranhão. O jesuíta foi um dos principais propagadores da ideia de que as guerras neerlandesas seriam vencidas principalmente pelos índios sob o comando dos religiosos. Advertiu, em 1637, as autoridades metropolitanas afirmando que "se os índios nos faltarem (...) havemos de despejar a terra". O rei estaria em "grande obrigação" com vários grupos indígenas pelos "grandes serviços” realizados nas guerras contra neerlandeses. ${ }^{83}$

\section{Tabela 2 - Moradores no Estado do Maranhão em fevereiro de 1637}

\begin{tabular}{|l|c|c|c|c|}
\hline \multicolumn{1}{|c|}{ Local } & $\begin{array}{c}\text { São Luís } \\
\text { (capital) }\end{array}$ & Belém do Pará & Ceará & Curupá \\
\hline Habitantes & 250 & 80 & 30 & 30 \\
\hline Soldados & 60 & 50 & 4 ou 5 & 0 \\
\hline Total & 310 & 130 & 34 ou 35 & 30 \\
\hline $\begin{array}{l}\text { Fonte: Relação do Estado do Maranhão por Bento Maciel Parente. In: Annaes da Bibliotheca } \\
\text { Nacional. Rio de Janeiro: Officina da Bibliotheca Nacional, vol. XXVI, 1904, p. 359. }\end{array}$ \\
\hline
\end{tabular}

${ }^{82}$ IAGHP. Coleção José Higino. Dagelijkse Notulen (Nótulas diárias, cópia do século XIX), vol. 4, 1638, 13 de dezembro de 1638.

${ }^{83}$ FIGUEIRA, Luís. Memorial sobre a gente as terras e a gente do Maranhão e Grão-Pará e rio das Amazonas. In: LEITE, Serafim. Luiz Figueira, sua vida heróica e sua obra literária. Lisboa: Agência Geral das Colônias, 1940, p. 208. 
O jesuíta era também um entusiasta das qualidades bélicas e da competência estratégica dos índios. Na Relação escrita em 1631, Figueira revela um episódio que envolveu um guerreiro potiguar chamado de Caragatajuba. O potiguar, ao ver que alguns índios estavam aliados aos neerlandeses, "toma espada na boca, lança-se a nado", danificando, uma a uma, as canoas inimigas até que nenhuma mais conseguisse flutuar. Certa vez, em outra batalha fluvial, Caragatajuba tentou capturar com vida um desses traidores nativos; "sem dúvida o trouxera", conclui Figueira, caso não fosse a intervenção de cerca de cinco holandeses que a golpes de cutelo impediram o resgate. Figueira sugeriu, deste modo, que o êxito na guerra contra a WIC não dependia dos soldados portugueses, ou mesmo da munição e armamento europeus, mas da presença de religiosos que "domestiquem o gentio".

Sem depreciar a importância das armas portuguesas, Figueira exaltava o serviço dos padres nessa guerra, pois "ainda que não pode haver religiosos sem armas, contudo por demais importância [tem que] haver religiosos [mais] que armas, para tal fim. Porque por armas não hão de deixar de vir estrangeiros a fazer tabaco". ${ }^{84}$ Figueira aproveitava-se da notoriedade que já tinham os guerreiros de nações indígenas no Brasil, onde mostraram o seu poder de destruição e combatendo os neerlandeses. ${ }^{85}$

Em novembro de 1640, uma força naval da WIC, comandada por Jan Cornelisz Lichthardt e Hans Koin, tomou a ilha de São Luís. Enquanto Figueira estava em Portugal, seus confrades Lopo do Couto e Benedito Amodei se estabeleceram em Tapuitapera (no continente), defronte da ilha onde se fortificaram os neerlandeses. Os neerlandeses, após os diversos ataques, deixaram São Luís aos 28 de fevereiro de 1644, "Com mayor segredo e pressa" ${ }^{86}$

O mês de fevereiro marcou a derrota dos neerlandeses não apenas no Maranhão, mas no Ceará também. Numa nótula, a de 9 de março, do Alto Conselho do Recife:

O Escolteto e os Escabinos de Rio Grande conciliam através da missiva da data de 16 de Fevereiro, que da redação do iate de Hasewint, que vindo do Maranhão passou lá,

${ }^{84}$ FIGUEIRA, Luís. Relação de vários sucessos acontecidos no Maranhão e Grão-Pará, assim de paz como de guerra, contra o rebelde holandês, ingleses e franceses e outras nações. 1631. In: Ibidem, p. 175.

${ }^{85}$ CARDOZO, Alirio. Notícias do norte: primeiros relatos da presença holandesa na Amazônia brasileira (século XVII). In: Nuevo mundo mundos nuevos, Debates. 2008, [Em linha], URL: http://nuevomundo.revues.org/43703. Acesso em 9 de junho 2010.

${ }_{86}$ AHU, Maranhão. Caixa 2, Documento 158. São Luís, 3 de agosto de 1644. Carta da câmara da cidade de São Luís ao rei d. João IV sobre a traição dos holandeses e a sua expulsão com ajuda dos índios região. 
não podiam concluir outra coisa senão que os Brasileiros do Ceará fizeram uma revolta, tomaram de surpresa e massacraram a nossa guarnição do forte, como também relataram os Papoyas que estiveram há pouco naquela capitania, e esses Papoyas trouxeram de lá uma grande quantidade de flechas de cana, dizendo que com isso iriam guerrear com uma outra nação de Papoyas inimigos e que eles estão com medo que isso se dirija a eles, e como eles têm muito pouca defesa por causa da extensão das suas moradias, eles pedem que em Mappabu, sendo o centro da capitania, possam ter uns soldados em guarnição, para deixar os Brasileiros dessa capitania num enorme temor. ${ }^{87}$

A participação dos índios e os nomes dos principais que atuaram na expulsão dos neerlandeses do Maranhão e Ceará foram suprimidos das crônicas jesuíticas maranhenses, todas redigidas mais de cinquenta anos após o fim das guerras. Apesar disto, uma representação manuscrita de 1644 ao Conselho Ultramarino em Lisboa permite recuperar o nome das lideranças indígenas que se opuseram aos neerlandeses.

Certo João Vasco levou, do Maranhão para Lisboa, um aviso em que representou a d. João IV “como os indios prinsipais (sic) q seruirão a Vmg. ${ }^{\text {de }}$ na redusão, e expulsão dos olandeses da cidade de São Luis do maranhão". Foram apontados os nomes dos seguintes principais: Bastião Gayagara, Francisco Yabaqua (ou Yabaca) Vicente Tapinamba, Tiago Tapahia, Jacaretinga (Jacaré Branco), Pero Tapahia, este último da aldeia de Sergi, sendo que "todos estes gouernão cada hu sua aldea e são indios de confiansa”. No Ceará, os índios principais também foram decisivos na retomada aos neerlandeses da fortaleza instalada naquela região, destacando-se os principais Yacoruna Merim (Jacu Preto Pequeno), Taparatim da Serra, Orubu Acanga (Cabeça de Urubu) de Gicuacuara. Ao fim da lista apresentada por João Vasco, segue a observação: "Estes são os do Seara por nouas q teue de outros indios por lhe saber fallar a lingoa". ${ }^{88}$ Assinalemos que, a exceção de Jacaretinga, os principais do Maranhão já possuem nomenclatura cristã e compõem o circuito de aldeias da língua geral. Visto que não havia missões religiosas na região, os principais do Ceará e Camuci ainda não possuem nomes cristãos, ou seja, não foram batizados e não falavam a língua geral.

Na guerra entre portugueses e neerlandeses no Maranhão, a grande derrota foi sofrida pelos povos indígenas. Os neerlandeses "não soò troucherão a guerra Mas hua peste, trazendo consigo Indios com Bichigas, q he a peste desta terra" ${ }^{89}$

\footnotetext{
${ }^{87}$ IAGHP. Dagelijkse Notulen, vol. 10, 1644, 9 de março de 1644.

${ }^{88}$ AHU, Maranhão. Caixa 2, Documento 158. São Luís, 3 de agosto de 1644. Anexo 4.

${ }^{89}$ AHU, Maranhão. Caixa 2, Documento 158. São Luís, 3 de agosto de 1644.
} 
A varíola começou a dizimar as aldeias do Maranhão. Somam-se a isso as violências praticadas contra os índios pelos capitães donatários do Maranhão e do Pará. Antonio Vieira afirmou, em 1655, que em Belém havia mais de 1.500 casos de cativeiro ilícito de índios aguardando julgamento pela Lei de $1652 .{ }^{90}$ Em 1657 , o jesuíta estimou que, no Estado do Maranhão, “em espaço de quarenta anos se mataram e se destruíram por estas costas e sertões mais de dois milhões de índios, e mais de quinhentas povoações". ${ }^{91}$ Essa devastação que teve lugar entre os povos indígenas do Maranhão pode ser considerada um dos maiores desastres demográficos no processo de conquista da América.

Diante daquele desastre humano e cultural, a primeira edição da Arte da lingua brasilica possibilita, em alguma medida, o resgate da linguagem colonial em uso na primeira metade do século XVII. Uma nova edição da versão original da gramática de Figueira, em contrapartida a todas as reedições posteriores da Arte, que foram feitas sobre a de 1687 , permitiria compreender a diversidade e a dinâmica das línguas indígenas num período decisivo para a história da América portuguesa.

Recebido: 04/10/2010 - Aprovado: 04/07/2011.

${ }^{90}$ Códice da coleção particular do autor. Cartas do padre Antonio Vieyra da Companhia de Jesus (1647-1697). 73 folhas, fls.47-54v; A referida carta está publicada na coleção de Lúcio de Azevedo com menos de $20 \%$ do texto integral. No códice existem, ainda, outras cartas de Vieira e de d. João IV em 1650 que João Lúcio de Azevedo não conheceu quando publicou a biografia do jesuíta.

${ }^{91}$ AZEVEDO (ed.). Cartas do padre Antonio Vieira, vol. 1, op. cit., p. 449. 